EstAg 29 (1994) 307-351

\title{
Juan Escoto Eriúgena: la complicada filosofía de un difícil filósofo
}

\section{I.- BIOGRAFIA}

Juan Escoto Eriúgena nació allá por los años 810 en Ecotia Maior, y murió en el 877.

¿Quién fue Juan Escoto Eriúgena, o como apuntan otros autores Eriúgena? Sólo sabemos que es escocés, y que en su patria adquirió rudimentos de la lengua griega. ¿Y cómo sería su conocimiento del griego? Sospechamos que la misma que hoy tienen nuestros bachilleres y estudiantes de Letras de nuestras universidades: sólo rudimentos. Con todo, y por este conocimiento del griego, seguramente tendría algo de conocimiento de los Padres Orientales. ¿Este conocimiento lo adquirió en Oriente? Y aquí se hacen presentes las referencias legendarias sobre su estancia en Grecia. Con toda seguridad que su helenismo es fruto del renacimiento irlandés, que pasó luego a Escocia.

¿Fue clérigo o sólo laico? Sólo podemos decir que no adquirió ninguna dignidad eclesiástica; por lo menos, no consta, por lo que la mayoría de los historiadores se inclinan por una no-clericatura para el Eriúgena. Sí que se púede afirmar que su formación la debe a las escuelas monásticas, por lo que también esto nos hace ver a un individuo desconcertante: ¿monje, no-monje, clérigo, no-clérigo?

Sí que sabemos que por los años 840-877 su vida discurre en la corte de Carlos el Calvo. Pero de sus años anteriores su vida se pierde en la oscuridad.

Cuando en el 840 entra en la corte de Carlos el Calvo, allí comenta la obra de Marciano Capella De nuptiis philosophiae et Mercurii. El libro III de esta obra se titula Arte dialéctica, que va a influir en todo el pensamiento del Eriúgena.

En el año 851 publicada él su libro La predestinación contra el monje Godesalco, y por iniciativa del obispo de Reims, Hincmar; obra que no gustó ni al propio obispo de Reims. Hace también una traducción del Corpus areo- 
pagiticum, del griego, por encargo de Carlos el Calvo.. Esta obra es del emperador de Bizancio, Miguel Balbo, y que con anterioridad regaló a Ludovico Pío en el año 827. Y va a ejercer gran influencia en el pensamiento del Eriúgena. También la obra de Máximo el Confesor, Ambigua, de la que se servirá para su propia obra La división de la naturaleza. Lo mismo hizo con el libro de Gregorio Niseno, Hominis opificio.

La obra fundamental del Eriúgena es la División de la naturaleza, escrito de madurez, en donde su autor nos da la versión de su sistema filosófico-teológico bien trabado y coherente, pero con cierto tinte de panteísmo, que, pasados los siglos, Honorio III condenó en 1225.

\section{OBRAS DEL ERIUGENA.}

Las podemos dividir en dos apartados: obras originales y el otro de traducciones.

1.- Obras originales:

Exposición sobre la «Jerarquía celeste» del Pseudodionisio.

Exposición sobre la «Jerarquía eclesiástica» del Pseudodionisio.

Exposición o glosas sobre la «Teología mística» del Pseudodionisio.

Homilía al prólogo del Evangelio de San Juan.

Comentario al Evangelio según Juan (Tres fragmentos).

La predestinación.

La división de la naturaleza

Comentario al Evangelio según Juan (fragmento IV).

Poesías

\section{2.- Traducciones}

Traducciones del Pseudodionisio:

La celeste Jerarquía.

La jerarquía eclesiástica.

Los nombres divinos.

Teología mística.

Cartas del Pseudodionisio.

Traducción de la obra de Máximo el Confesor:

Los ambiguos 
Fuentes de las que se sirve el Eriúgena:

Para La predestinación no tiene más obras que la Patrología Latina. Y muestra influencias neoplatónicas a través de San Agustín. También influyen en él San Jerónimo y San Ambrosio. Y no digamos nada del Pseudodionisio tan presente en él. Acusa influjos de San Gregorio Magno y San Isidoro. Otras fuentes para él serían Marciano Capella, San Hilario de Poitieres, Boecio, por medio del cual conoce a Aristóteles y a Pitágoras. Parece que también influyen en él los hebreos, aunquø̛él desconoce su idioma, por referencias que hace a la tradición cabalística, puesto que ésta no es ignorada en Occidente. Una cosa podemos afirmar: dentro de lo desconcertante de la doctrina del Eriúgena, también este tema de las fuentes se nos muestra desconcertante.

\section{LECTURA DEL ERIUGENA}

El Eriúgena identifica religión y filosofía con estas palabras:

"Hay que sostener que la verdadera filosofía es la verdadera religión y por conversión hay que afirmar que la verdadera religión es la verdadera filosofía" ${ }^{1}$.

Por lo que el cometido de a filosofía consiste en la exposición de las normas de la verdadera religión ${ }^{2}$. Pensemos que todo esto no es más que una derivación agustiniana entre fe y razón ${ }^{3}$. Por lo que llegamos a la conclusión de que entre la autoridad de las Sagradas Escrituras y la recta y verdadera razón hay una perfecta armonía. Todo dentro de la capacidad humana para el conocimiento de Dios. Por lo que el Eriúgena estatuye tres movimientos o grados en el conocer: los sentidos, que sólo captan las apariencias de las cosas materiales; la razón, con la que se llega a conocer a Dios como causa de esas cosas, pero sin llegar a alcanzar su esencia; y la inteligencia -como intellectus-animus - con la que se alcanza en visión inmediata al Dios invisible, sobrepasando todo lo de la naturaleza humana y del mundo de las cosas materiales.

Por lo tanto, el hombre no conoce a Dios desde el exterior, sino entrando a sí mismo y en sí mismo -agustinismo ${ }^{4}$ - en donde se encuentra con la

1. De praedestinatione, cap. 1, PL. 122, 357-358.

2. Ibidem, ibidem.

3. SAN AGUSTIN: De vera religione, 5, 6. PL. 34, 126.

4. SAN AGustin: De vera religione, 39, 72. PL 34, 154. 
trinidad sustancial de su mente y en donde se hace presente Dios. Este el último grado-paso y es el único camino para llegar al conocimiento de la verdad $^{5}$.

Razón y autoridad no pueden oponerse entre sí, pues las dos derivan de una y única fuente, de la sabiduría divina. La autoridad procede de la razón verdadera, pero la razón no dímana de la autoridad. Por lo que la autoridad que no provenga de la razón se nos muestra como sin valor. Porque la razón auténtica tiene su propia energía y no necesita del apoyo d ninguna autoridad $^{6}$. ¿Y cuál es la verdadera razón para el Eriúgena? La Sagrada Escritura, que al mismo tiempo es autoridad y razón. Por lo que una autoridad no razonada no es autoridad ${ }^{7}$. En todo esto el Eriúgena sigue la tradición patrística.

Para entender al Eriúgena tenemos que pensar en lo siguiente: que la verdadera filosofía -para él- es la verdadera religión, como ya hemos dicho; y que la verdadera religión es la filosofía verdadera, como lo confirma Hegel $^{8}$. Pero tenemos que pensar que, para Hegel, toda la filosofía auténtica es la expresión de una religión contenida en la claridad de la reflexión pasional. «Por eso, la filosofía y la teología se consideran aquí como una misma cosa» ${ }^{9}$.

Por lo que, dentro de la pobreza cultural de su tiempo, este hombre se levanta como el prototipo de investigación y reflexión filosófico-teológica. «La cultura y capacidad especulativa de Juan Escoto le pone muy por encima del nivel de sus contemporáneos. No solo conoce el griego y traduce esta lengua, sino que saca de los escritơres y del espíritu griego una gran libertad de investigación y de orientación especulativa» ${ }^{10}$.

En lo que se refiere a sus traducciones Émile Bréhier dice: «La traducción de Juan no es una verdadera traducción en el sentido que hoy damos a este término; es, como casi todas las traducciones de la edad media, un calco, palabra por palabra, de fidelidad desoladora que induce a penar que el autor, como si fuera un mediocre escolar, no conseguía hallar el sentido de la frase sino después de haber traducido separadamente cada palabra» ${ }^{11}$.

\footnotetext{
5. De divisione naturae, II, 32, PL 122, 610-619.

6. De divisione Naturae, I, 69. PL. 122, 513.

7. Ibidem, ibidem.

8. HEGEl: Lecciones sobre la historia de la filosofia, pág. 123; tomo III; F. C. E. México,

9. HeGEL: obra citada, pág. 106.

10. Abbagnano, N: Hisctoria de la filosofía, tomo I, pág. 269; Ed. Montaner y Simón, S. A.

11. BRÉHIER, E: Historia de la filosofía; tomo I, pág. 504; Ed. Sudamerica; Buenos Aires,
} 1977. Barcelona, 1955. 1944. 
IV.- RELACION ENTRE FE Y RAZON.

Es una cuestión ya debatida en la doctrina agustiniana. De acuerdo con San Agustín, el Eriúgena parte del presupuesto de que existe una íntima trabazón de concordia entre razón y fe.

"La verdadera autoridad no obstaculiza a la recta razón, ni la recta razón obstaculiza a la verdadera autoridad. No hay duda que ambas proceden de una fuente única, esto es, de la sabiduría divina" ${ }^{12}$.

En la Homilía sobre el Evangelio de San Juan dice que la luz divina se manifiesta sobre el mundo de dos maneras: por la Escritura y mediante la criatura, que son algo así como dos vestiduras de Cristo. Todo lo que vemos y con lo que nos encontramos es epifanía de Dios; pero, al mismo tiempo, un velo que lo oculta. La búsqueda de Dios consistirá en correr-desvelar ese velo y descubrir el rostro de Dios, por lo que nadie entra en el cielo sino mediante la filosofía. Luego la verdadera filosofía y la verdadera religión son una misma cosa para el Eriúgena.

No puede haber contradicción entre fe y razón; y si la hubiera, nunca esta contradicción vendría de la fe o de la razón, sino de la mala interpretación del hombre, que no capta bien los argumentos de la razón o las pruebas de la fe.

"No hay salvación para las almas de los fieles, si no es en el creer en lo que se dice con verdad sobre el único principio de las cosas, y en el entendimiento de lo que con verdad se cree" ${ }^{13}$.

No obstante, la mayor dignidad y primacía de naturaleza corresponde a la razón y no a la autoridad; porque la razón nació al principio de los tiempos, junto con la naturaleza. La autoridad vino más tarde. Por lo que la autoridad debe ser aprobada por la razón. La razón no necesita apoyo alguno, porque ella no es otra cosa que la verdad descubierta en virtud de la razón de los santos Padres y por ellos transmitida ${ }^{14}$. Por lo tanto se debe seguir a la razón, que es la que busca la verdad; y no debe ser oprimida por ninguna autoridad.

Esto no implica, en manera alguna, una negación de la religión en el Eriúgena. Lo que él quiere demostrar es la supremacía de la razón sobre la

12. De divisione naturae, I, 66; PL 122, $511 \mathrm{~B}$.

13. Ibidem, I, 20; P1 122, 556.

14. Ibidem, I, 69; PL 122, 513 B-C. 
autoridad y dejar paso abierto a la razón-filosofía en la búsqueda de la verdad. Y hay que tener presente que, para el Eriúgena, la religión no se identifica con la autoridad, sino con la búsqueda de la verdad. Por lo tanto, religión y filosofía, en él, son una misma cosa.

“¿Qué quiere decir tratar de filosofía, sino poner las reglas de la verdadera religión, por las cuales la causa suma y principal de todas las cosas -Dios- es humildemente adorada y racionalmente investigada?" ${ }^{15}$.

Por lo tanto,

"que nadie te atormente por estas cosas, porque la contemplación enseña el razonable conocimiento" 16 .

Ya está apuntado, aparentemente, el aire panteísta en el Eriúgena, porque -para él- el conocimiento es una especie de auto-conocimiento de Dios realizado en nosotros. Por lo que él explica la frase de Cristo no sois vosotros quienes habláis, sino que es Dios quien habla en vosotros en estos términos:

"No sois vosotros los que me entendéis, sino yo el que me entiendo a mí mismo en vosotros a través del Espíritu" ${ }^{17}$.

Por lo que él toma la palabra divina para el comienzo de su razonar filosófico. Y por lo que también él interpreta la palabra de Dios a su modo, y muchas veces en un sentido muy acomodaticio. Con frecuencia distorsiona el texto para llevar el agua a su molino, distanciándose del verdadero sentido bíblico.

\section{V.- PRINCIPIOS DE SU FILOSOFIA}

Para una mejor comprensión del pensamiento del Eriúgena vamos a dar unos puntos que aclararán un poco su modo de pensar. El primero es

\section{Su idealismo}

No hay que perder de vista la época en que vive, toda ella neoplatonizante, por lo que para él el universal explica mejor la realidad objetiva de las

\footnotetext{
15. De praedestinatione, II; PL 122, $357 \mathrm{D}$.

16. De divisione naturae, I, 66; PL 122, $511 \mathrm{~B}$.

17. Homilia in Toan. Evang. PL 122, 191 D.
} 
determinaciones lógicas universales, de todos los conceptos de género y especie, que expresan mejor y más perfectamente el mundo de la concreciones individuales. Antes que nada debemos considerar el universal en donde lo particular está contenido. Por eso él dice que las cosas mismas subsisten más verdadera y ciertamente en sus nociones que en sí mismas.

La realidad de todo es su concepto, con estas palabras suyas:

“¿Por qué nos vamos a extrañar de la noción que la mente humana posee... de las cosas cuya noción se entiende como sustancia..., si llamamos noción de diferencias y propiedades que son accidentes?" 18 .

Cuando más universal es un concepto tanto mayor es su realidad objetiva. Por lo tanto, los conceptos de los géneros supremos son más reales que los conceptos menos extensos y éstos más que las especies en que todo género se divide. Los individuos se encontrarán en la periferia de la realidad, que casi linda con la nada.

Cuando comenta la palabra bíblica de la creación, quiere ver a Dios creando, primero, el género -el universal-, porque en él se contiene y se dan juntas todas las especies.

"Primeramente puso el género, porque en él todas las especies se contienen y son una misma cosa" 19 .

En su interpretación bíblica el Eriúgena ve, no la producción de un modo espacio-temporal, sino la creación de la realidad profunda de cuanto existe y puede existir, y que pertenece al campo de lo eidético; y esto que llamamos en realidad no es. sino una desvaída y simplista manifestación fenoménica. A partir de la realidad profunda, como de una fuente inmensa, se abre una como catarata en todas direcciones y se extiende y diversifica hasta alcanzar el campo de los cuerpos individuales, que quedan afectados por las limitaciones espacio-temporales.

Por lo tanto, podemos concluir que, siguiendo al Eriúgena, si el proceso inmanente de la realidad va desde las líneas más universales hasta los individuos -seres concretos-, quien quiera usar rectamente de la dialéctica, la lógica, debe comenzar por el estudio de la realidad a partir de las ideas más universales.

18. De divisione naturae, IV, 7; PL 122, 769 b.

19. Ibidem, IV, 4; PL 122, 748 D. 
"Quien trate de dividir rectamente debe comenzar por lo más general-universal; y desde aquí, salir, y así, en la medida que la contemplación progresa, debe llegar hasta lo más particular" 20.

La esencia es la determinación real más objetiva. Por consiguiente, es incorpórea, simple e indivisible ${ }^{21}$. Existe en todo; en los géneros y en las especies; pero no queda coartada, sino que permanece inmultiplicada. Todas las cosas se adhieren a ella, en ella subsisten y sin ella nada puede existir ni consistir ${ }^{22}$.

"Subsiste toda junta e inconmutablemente en sus subdivisiones, y todas sus subdivisiones son, a la vez, y siempre lo mismo e inseparable en su misma unidad" ${ }^{23}$.

Por lo mismo, la esencia de las cosas es una sola, es decir, Dios mismo, porque Él es la esencia de todo y el que sólo es verdaderamente.

Esta esencia es incognoscible e incomprensible en sí misma. Lo que se capta con los sentidos y se comprende con el entendimiento en todo ser creado es sólo lo accidental de la incomprensible esencia de Dios. Así, entonces, Dios, no sólo es la esencia de todas las cosas, sino también sus teofanías. Y sólo gracias a éstas podemos conocerlo ${ }^{24}$. De Dios sólo podemos afirmar que es, pero no qué es, porque su esencia es indefinible e incomprensible.

"Nadie puede definir ni decir qué es la «ousía» por sí misma" 25.

También la esencia de Dios es el punto de arranque de todos los géneros y formas que permanecen en la existencia, porque siguen fundamentándose en ella.

$Y$ todas estas cosas, es decir, los géneros y las formas provienen-emanan de la única fuente de la «ousía», y vuelven a ella por un movimiento natural ${ }^{26}$.

Las cantidades y las calidades, en cuanto se piensan en sí mismas, son incorpóreas y no s encuentran en nada más que en la «ousía» a la que acceden, subsisten e inseparablemente en ella se quedan ${ }^{27}$.

20. Ibidem, III, 3; PL 122, 496.

21. Ibidem, I, 53; PL 122, 496.

22. Ibidem, I, 3; PL 122, 478 A-D.

23. Ibidem, I, 49; PL 122, 492 c.

24. Ibidem, I, 7; PL 122, 443 D.

25. Ibidem, I, 45; PL 122, 487 B.

26. Ibidem, I, 52; P1 122, 494 B.

27. Ibidem, I, 53; P1 122, 496 D. 
Hay una marcada diferencia entre Marciano Capella en el Eriúgena, sobre todo, por la obra del primero, De nuptiis philosophiae et Mercurri, que el Eriúgena tradujo en su juventud. Para Capella son cuatro las operaciones de la dialéctica:

1.- división,

2.- resolución,

3.- definición y

4.- demostración.

Para el Eriúgena son sólo dos:

1.- división y

2.- resolución.

Y para él la dialéctica se define con estas palabras:

Lo propio de la dialéctica, «cuyo objetivo es dividir la naturaleza de todas las cosas, unirlas, discernirlas y distribuirlas en sus lugares propios...» ${ }^{28}$.

Escoto Eriúgena da esta reducción por el carácter metafísico que en la naturaleza se encierra tanto la división como la resolución. La dialéctica del Eriúgena es realista, puesto que es un buen neoplatónico; y presupone la realidad objetiva de cualquier determinación universal, de todos los conceptos de género y especie. $\mathrm{Y}$ en este sentido se precisa que, cuanto más universal sea una idea-concepto, más realidad objetiva encarna. Por lo que el concepto de género es más real que el de las especies, que son más particulares y menos extensas; $y$, por lo mismo, también los individuos tienen menos realidad objetiva que las especies, a las que siguen en la escala de descenso en la realidad.

"El arte que divide los géneros en las especies, y resuelve las especies y los géneros, que es la dialéctica, no ha sido creado por el ingenio humano, sino que está fundado en la misma naturaleza, y ha sido creado por el autor de todas las artes que son artes verdaderas, descubiertas por los sabios para el provecho de toda clase de investigaciones sobre cosas" ${ }^{29}$.

28. Ibidem, I, 44; Pl 122, 486 B.

29. Ibidem, IV, 4; PI 122, 749 A. 
Lo más universal de todo, considerado lógicamente, es la esencia -ousía-, y es incorpórea, simple e indivisible. Ella existe en todo: en los géneros y en las especies; pero no se divide en ellos, sino que permanece simple-inmultiplicada, aunque no se vea multiplicada en los géneros, especies e individuos ${ }^{30}$.

"La esencia subsiste toda junta; es eterna e inconmutablemente en sus subdivisiones; y éstas constituyen simultáneamente y siempre en ella una unidad inseparable" 31 .

La esencia -ousía- es también incognoscible e incomprensible, como Dios mismo. Lo que se percibe con los sentidos o se comprende con el entendimiento en toda criatura es sólo algo de los accidentes de la incomprensible esencia ${ }^{32}$.

Cuando el Eriúgena trata de titular su obra la división de la naturaleza, sólo alude a la división, porque se da cuenta de que la otra cualidad -la resolución- sigue a al división, como la sombra al cuerpo. El divide el género de los seres en tres grandes grupos:

1.- seres que son entendidos y entienden.

2.- seres que son entendidos y no entienden y

3.- seres que ni son entendidos ni entienden.

Él sitúa la definición en el grupo primero, en el de seres que son entendidos y entienden ${ }^{33}$. Con lo que sustituye la definición en sí misma por el acto de definir y lo definido por lo definiente.

«La acción de la definición del que razona y entiende es una acción de la naturaleza» ${ }^{34}$.

Y establece este principio:

«Ninguna naturaleza, que no se comprenda a sí misma como existente o igual a sí inferior o a sí misma inferior, no se puede definir» ${ }^{35}$.

Por lo que sospechamos que, cuando el Eriúgena habla de definición, se refiere a un conocimiento sustancial de la realidad definida. Un poco más adelante dice:

30. Ibidem, I, 34; PL 122, 479 A-C.

31. Ibidem, I, 49; Pl 122, $492 \mathrm{C}$

32. Ibidem, I, 3; Pl 122, 443 B.

33. Ibidem, i, 43; Pl 122, $484 \mathrm{D}$.

34. Ibidem, I, 43; PL 122, 485 A.

35. Ibidem, I, 43; PL 122, 485 A. 
«Es mayor lo que define que lo que es definido... Me parece concluir por esta razón no poder definir racionalmente otras naturalezas inferiores a sí mismas» ${ }^{36}$.

Nos parece que cuando Escoto Eriúgena está hablando de la definición, se refiere a un conocimiento sustancial de la realidad definida. Pero aún es más fuerte lo que dice a continuación:

«Por lo tanto, donde hay definiciones de lo que se define, allí mismo existe el lugar que lo circunscribe» ${ }^{37}$.

Y concluye: por consiguiente, como el alma racional es incorpórea, necesariamente todo lo que en ella se entiende tiene que ser incorpóreo también ${ }^{38}$. Por lo que nosotros decimos que la realidad exterior conocida, por el hecho mismo de serlo, consigue el carácter espiritual de la mente que la conoce. Por lo que él mismo termina con esta afirmación de tipo panteísta:

«Si, pues, todo entendimiento, exceptuando el de Dios, no se circunscribe a sí mismo, sino por algo superior, ningún entendimiento tendrá lugar para sí, si no fuera colocado dentro del superior» ${ }^{39}$.

Que es lo mismo que decir que nuestro entendimiento no es otra cosa que el reflejo del divino, que piensa en nosotros. Por lo que el entendimiento divino es colocado por el Eriúgena como el lugar natural, el abarcador de todo otro conocimiento; y éste, a su vez de toda la realidad por él conocida. Por lo que sólo la dialéctica nos da el verdadero conocimiento de la realidad ${ }^{40}$.

Para él la dialéctica es como un proceso por el que toda la realidad desciende de los conceptos universales y abstractos y de las causas primordiales hacia lo concreto de los seres; y esto es la resolución-recollectio-o análisis.

«Toda división, que los griegos llaman $\mu \in p \iota \sigma \mu o ́ s$, es como una bajada desde un algo indefinido al número fijado, es decir, desde lo más general hasta lo más particular. Con todo, la resolución es como una vuelta, comenzando desde lo

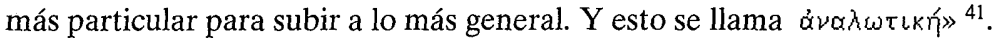

Por lo tanto, tenemos que tener muy en cuenta todo esto: comenzar desde lo universal para bajar a lo.individual.

36. Ibidem, I, 43; PL 122, 485 B.

37. Ibidem I, 43, PL 122, 485 B.

38. Ibidem, ibidem.

39. Ibidem, I, 43, PL 122, 486 B.

40. Ibidem, I, 44; PL 122, 487 A y B.

41. Ibidem, II, 1; PL 122, 526 B. 
«Pues quien divide rectamente debe comenzar por lo muy general para ir a lo más general, y así llegar según la energía de la contemplación, a lo más particular» ${ }^{42}$.

Por lo que la división debe partir de lo universal-general para, pasando por géneros y especies, llegar a lo singular de los seres-individuos de la naturaleza. El análisis sigue el camino inverso: de lo singular ser-individuo llegar hasta lo más simple de todo lo existente, al género supremo. Por lo que todo este proceso dialéctico será un acceso a la división y síntesis de opuestos por medio de la negatividad.

«Cada orden... puede decir que es y que no es. La afirmación de lo inferior es negación de lo superior. Del mismo modo, la afirmación de lo superior es negación de lo inferior. En realidad la negación de lo superior será afirmada de lo inferior... Se puede observar, por la misma regla, en todas las esencias celestes, hasta llegar al orden supremo de todo. El mismo orden se termina-completa desde arriba con la negación» ${ }^{43}$.

Esto es lo que Escoto Eriúgena llama negatividad o vía de la negatividad. La negatividad es, al mismo tiempo, ser y no-ser; y esto a todos los niveles y en todas sus manifestaciones. Pero el no-ser del Eriúgena no es simplemente lo equivalente a la nada:

«La ausencia y privaciones de las cosas que existen no son seres que completamente no existan» ${ }^{44}$.

El Eriúgena habla de cinco sentidos del ser:

1.- Es necesario atribuir a Dios y a toda esencia el no-ser en el sentido de que supera todo conocimiento ${ }^{45}$.

2.- La esencia superior es no-ser comparada con la esencia inferior, porque, justamente, en ella se completa su ser; pero al mismo tiempo la inferior es no-ser comparada con la superior, porque no goza de la plenitud del ser que la superior posee.

3.- También es no-ser lo que todavía es ser virtual, lo que aún no ha alcanzado la existencia, lo que permanece como semilla aún sin germinar.

4.- La materia y los cuerpos son no-ser con razón y por oposición a los seres espirituales, que son los que verdaderamente son, porque en ellos las cosas materiales encuentran su sentido y su suștancia.

42. Ibidem, III, 3; PL 122, 628 C.

43. Ibidem, I, 4; PL 122, $44 \mathrm{~B}$.

44. Ibidem, I, 3; PL 122, 443 C y D.

45. Ibidem, I, 3; PL 122, 443 A. 
5.- En último lugar tenemos el ser del hombre pecador, que es un no-ser comprado con el ser de la naturaleza humana restaurada por la gracia ${ }^{46}$.

Pienso que esta disertación del ser y del no-ser es un disparadero de la realidad, porque de la negación de la realidad superior se produce la creación de la realidad inferior y de la negación de la realidad inferior se alcanza de nuevo la plenitud de la realidad superior.

En todo está, en primer lugar, la división, el descenso de la realidad superior hacia la inferior, que es el mundo atravesado por la negatividad de la contingencia, el mundo espacio-temporal, que es negación de la realidad superior. Así nos lo describe al hablar de la creación, que no fue sino un proceso de negación:

«Así, pues, de la superesencialidad de su naturaleza, en la que se dice el no-ser, descendiendo primeramente, por sí mismo crea en las causas primordiales y se constituye en el principio de toda esencia... Y así se hace todo de la nada. De su superesencialidad produce las esencias; de la supervitalidad, las vidas; de la superintelectualidad produce las esencias; de la supervitalidad, las vidas; de la superintelecutalidad, al entender-entendimiento; de la negación de todas las cosas, las que son y las que no son; de las afirmaciones de todas las cosas, las que son y de las que no son» ${ }^{47}$.

«Ciertamente, como todo el río viene principalmente de la fuente y por su madre discurre el agua -que sale primero de la fuente-, en cuanto discurre en toda su largura sin interrupción, de la misma manera la bondad divina, la sabiduría y todas las cosas -que en el manantial son una misma-, en primer lugar fluye a las causas primordiales y hacen que sean ellas, y luego pasan a los efectos de las mismas, por un inefable modo, siempre saliendo de lo superior a lo inferior; y una vez más vuelven a su origen a través de unos ocultos caminos por un muy alto paso. De ahí, pues, procede todo bien, toda esencia, vida, sentido, razón, sabiduría, género, especie, belleza, diferencia, espacio, tiempo y todo lo que es y no es, y todo lo que se entiende y se siente, y todo lo que supera el sentido y el entendimiento» ${ }^{48}$.

Este proceso, por consiguiente, se produce desde la causa de las causas -la fuente- a las otras causas primordiales; $y$, desde éstas a sus efectos o concreciones espacio-temporales hasta alcanzar la periferia del mundo material, en donde toda la realidad contiene la menor consistencia de ser y que es donde, y también, se encuentra como aprisionada por la finitud-contingencia del espacio y tiempo ${ }^{49}$. Esto parece indicar que en la realidad superior está comprendida la inferior, no tal como se da en la inferior, sino en grado superior.

46. Ibidem, I, 3-7; PL 122, 443-447.

47. Ibidem, III, 20; PL 122, 683 A y B.

48. Ibidem, II, 4; PL 122, 632 B-D.

49. Ibidem, I, 40; PL 122, 88 A, B y C. 
La dialéctica de Escoto Eriúgena no se concreta sólo a la división, porque quedaría incompleta su manera de apreciar el ser, sino que hace intervenir en su pensamiento otro elemento: el análisis, que es su segundo momento. El análisis es como un reunir... distribuir a cada cosa a sus propios lugares ${ }^{50}$.

El paso de la división al análisis se realiza también a base de la negación, y que -negación de la negación- no supone el rompimiento con la realidad espacio-temporal, sino su superación, o su trascendencia, como él llama a todo este tinglado. En el proceso de la dialéctica nada se destruye o muere ${ }^{51}$, sino que pervive sublimado en la estructura superior.

«¿Cómo puede desaparecer lo que se comprueba que se convierte en mejor?» 52 .

«Ciertamente, lo inferior se siente atraído de forma natural por lo superior, y se absorben, no para que no sean, sino para que más se salven y subsistan y sean uno» ${ }^{53}$.

Todo lo que vuelve o retorna a la fuente, no aumenta la fuente, donde ya estaba todo, sino lo que todo que de ella brotó y salió, al reintegrarse en la misma, se sublima divinizándose y transformándose en Dios.

«Pues sólo Dios aparecería en las mismas (en las causas eternas), cuando sobrepasan los linderos de su naturaleza, no para que desaparezca en ellas la naturaleza, sino para que él sólo aparezca en ellas, el que sólo existe de verdad. Esto es trascender la naturaleza, no es mostrarse a la naturaleza, como el aire -según hemos visto muchas veces- no aparece lleno de luz, porque solamente la luz reina» ${ }^{54}$.

Todo procede de la unidad, que es el centro desde donde todo se desborda en catarata hacia la periferia, donde la luz se apaga en la lejanía de la nada ${ }^{55}$.

La naturaleza divina es el punto de donde parte la multiplicidad de lo real: de ella comienza toda división y alumbramiento ${ }^{56}$ de las cualidades y esencias, aun de aquellas que son entre sí diferentes e incluso contrarias. Todo se reúne y unifica en el centro, y allí se consigue la armonía de su existencia conjunta y plena:

«Todas las líneas se juntan en el centro, tanto que no se las puede distinguir unas de otras, porque, con toda certeza son unas en él y no se las puede distin-

50. Ibidem, I, 7: PL 122, 874 C y D.

52. Ibidem, V, 8; PL $122876 \mathrm{~B}$.

53. Ibidem, V, 8; PL 122, 879 A

54. Ibidem, I, 40; PL 122, 483 A.

55. Ibidem, III, 3 y 4; PL 122, 628-634. 
guir; así, racionalmente, no forman unidad de líneas, lo mismo el origen y principio simple e indivisible del que, de manera natural, o por el arte, procede el número variado de líneas, se delimita el centro en que todos concurren en unidad» 57 .

Cuanto más las líneas se separan del centro, más se aprecia la diferencia y separación entre sí mismas; y, por tanto, se debilita su realidad, dando en ello motivo para que entre la ingerencia de la nada ${ }^{58}$.

\section{LA NATURALEZA}

\section{A.- Qué se entiende por naturaleza}

Después de estudiar la división-síntesis de la realidad, el Eriúgena trata también de la naturaleza, que es una parte fundamental de su dialéctica. Con el término naturaleza quiere expresar el contenido de la realidad, no como algo estático, como una ousía, sino como un proceso o como una phisis. Porque -piensa él-, tanto para los griegos como para los latinos, el termino ousía es intercambiable, en principio, por el de phisis y adquiere un matiz diferenciador.

«Por lo tanto, toda criatura es «ousía en cuanto se mantiene en sus razones y en cuanto se engendra en alguna materia es «phisis» (naturaleza)» ${ }^{59}$.

Por lo que él prefiere el término phsisis, porque le va mejor para su exposición sobre la esencia en el aspecto doble y dinámico de expansión y reabsorción.

«Lo primero que se trata con la «ousía», como algo propio en donde procede la división..., arranca por géneros muy particulares y géneros medios, descendiendo hasta las formas y especies más particulares, se llega de nuevo, por los mismos grados y por la norma de la reunión, a los que se regresa hasta la misma «ousía», de donde sale y no cesa de volver a ella en donde desea descansar y a su alrededor solamente se desenvuelve, y si se quiere, con movimiento inteligible» ${ }^{60}$.

56. Ibidem, II, 4; PL 122, 632-634.

57. Ibidem, III, 1; PL 122, 625 A.

58. Ibidem, ibidem; PL 122, 625 A-D.

59. Ibidem, V, 3; PL 122, 867 A y B.

60. Ibidem, V, 3; PL 122, 869 A. 
Al preferir el término naturaleza está indicando que, siendo de carácter dinámico, es también el término universal que excede, incluso, la universalidad del ser, porque -y también- expresa e implica la universalidad del mismo ser.

«Como dijimos, la naturaleza es un nombre genérico, de lo que es y de lo que no es» 61 .

Ya lo había dicho Platón en el Parménides y en el Sofista, donde también se considera al ser como naturaleza, como algo abarcador del ser y del no-ser.

Así como en la división de la naturaleza en ser y no ser, la división también entra en Dios: en él se da la división suprema, entre sí mismo o en su esencia y Dios en sus teofanías, pero teniendo en cuenta que Dios es para Escoto ambas cosas.

«En verdad la primera y más profunda división es la del conjunto de naturaleza creadora... y creada ${ }^{62}$. Añadiste también que no sólo se llama Dios existente a la misma esencia existente inmutablemente en sí misma, sino también a las teofanías, que se pueden pronunciar con el nombre de Dios» ${ }^{63}$.

Por lo que la naturaleza divina se puede llamar ser en cuanto se manifiesta como teofanía y no-ser considerada en su esencia, porque sobrepasa todo entendimiento ${ }^{64}$. Pero puede ser considerada como ser en su esencia, porque de ella brota y en ella radica toda la realidad. Y también puede ser considerada como no-ser en sus teofanías, porque en ellas no alcanza la plenitud del ser que goza su esencia.

¿Influencia del platonismo? Platón habla de un mundo inteligible, mundo eterno y de las ideas y principios inmutables y ejemplares de la realidad sensible. «Naturaleza naturada por cuanto este mundo de verdades es fundado y constituido con eterna necesidad por Dios en cuanto naturaleza naturante no naturada» 65 .

B.- División de la naturaleza: las cuatro naturalezas.

\section{INTRODUCCION}

Repetimos que el punto de partida del Eriúgena, para su metafísica, es la división y de la división de la naturaleza en cuatro apartados o fases, como

61. Ibidem, proemio; PL 122, $441 \mathrm{~A}$.

62. Ibidem, II, 1; PL 122, 621 A-D.

63. Ibidem, I, 8; PL 122, 448 B.

64. Ibidem, I, 8; PL 122, 447-448.

65. CANAls Vidal F: Historia de la filosofía medieval, pág. 99, Ed. Herder, Barcelona, 1976. 
veremos un poco más adelante. Y que él entiende por naturaleza todo lo que existe y no existe. Se inspira en San Agustín, en La ciudad de Dios ${ }^{66}$. Tenemos que recordar también que, para Escoto Eriúgena, por el no-ser no se entiende la nada, sino sólo la negación de las varias determinaciones posibles del ser, todas las cuatro naturalezas se integran en el ser divino.

«En primer lugar, Dios desciende de la superesencialidad de su naturaleza, en la que se debe decir que él no es, y creado por sí mismo en las causas primeras, se convierte en el principio de toda esencia, de toda vida, de toda inteligencia y de todo lo que la teoría gnóstica considere como causas primordiales. En segundo lugar, él desciende a las causas primordiales, que están entre Dios y las criaturas, entre la inefable superesencialidad de Dios, que trasciende toda inteligencia, y la naturaleza que se manifiesta a los que tienen un espíritu puro; se encuentra en las causas primordiales, y se manifiesta abiertamente en sus teofanías. En tercer lugar, llega por medio de las formas múltiples de tales efectos hasta el último orden de la naturaleza entera que contiene los cuerpos. Así, procediendo ordenadamente en todas las cosas, las crea todas y se convierte todo en todo. Y regresa a sí mismo, volviendo a llamar a todas las cosas a sí, y mientras se encuentra en todas las cosas, no cesa de estar por encima de ellas ${ }^{67}$.

Hay en todo esto un salir, un estar en el mundo de todo y un regresar de todo al principio -neoplatonismo-, y esto constituye todo la trama central del pensamiento de Juan Escoto Eriúgena. Aquí está contenida la relación de Dios-mundo y de mundo-Dios, porque Dios es teofanía-manifestación a lo externo a sí. Pero Dios no es el mundo, porque al hacerse Dios en el mundo y convertirse en el mundo, Dios está por encima de él. Y así nos da esta división de la naturaleza:

«A mí me parece que la división de la naturaleza se debe hacer en cuatro maneras:

la primera es ésta: la que crea y no es creada;

la segunda, la que es creada y crea;

la tercera, la que es creada y no crea y

la cuarta, la que ni crea ni es creada» 68 .

Es claro que San Agustín tiene dos divisiones de la naturaleza en ese pasaje de La ciudad de Dios; pero el Eriúgena añade dos más: la creada non creas y la nec croata nec creas.

66. San Agustín: De civitate Dei, V, 9, 4 .

67. De divisione naturae, III, 20; PL 122, 683, A-B.

68. Ibidem, I, 1; PL 122, 441 B; II, PL 122, 525 C-D. 
A pesar de que muchos autores, al tratar de entender y dar el pensamiento de este oscurísimo Eriúgena, quieren ver cuatro naturalezas en el cosmos, con todo, no es más que una sola; y, por lo mismo, titula así su libro: De divisione natura y no naturarum, como sería lógico. También él nos dice que no hay sino una sola naturaleza, la divina, como principio y animadora de todo el proceso.

Esta es toda la historia cósmica, que no es otra cosa que la misma biografía de Dios, que saliendo de sí mismo, expande sus infinitas virtualidades en la realidad del mundo, sin dejar de ser él mismo -momento de contracción-sístole- para asumirlas e integrarlas en su profunda entraña-momento de dilatación-diástole-.

\section{1.- Natura creans nec creata = naturalez $a$ que crea y no es creada}

Es el primer paso en la división de la naturaleza. La naturaleza creante y no creada es Dios, la esencia divina en sí misma, sustancia absoluta e infinita, que, en cuanto tal, es inefable e incognoscible: por lo que desde una vista de la teología negativa hay que remover de Dios cualquier afirmación, porque decir que Dios es verdadero o sabio sería entrar en un sentido metafórico, transportado desde lo infinito a lo finito. Pero es que también existe la teología positiva o afirmativa, que dice algo de Dios, afirmando de él lo que de él quita la negativa. Y si afirmamos que Dios es verdadero, sabio, bueno..., queremos decir que lo que encontramos en lo infinito como tal, tiene su causa fundante en esta naturaleza increada.

La primera naturaleza es Dios, es la esencia divina en sí misma, porque ella es la causa de todas las causas y el principio increado de todo y del que todo procede como de una fuente arrolladora de vida. Ella es la causa principal de lo que de él y por él es creado. También es el fin-término del universo, que vuelve a él: es principio, medio y fin ${ }^{69}$. Pero, como principio, medio y fin, también ella es creada, creada por sí misma en las cosas que ella crea de la misma manera que nosotros creamos el pensamiento en su propio ser en los razonamientos que formulamos y hasta en las imágenes que se nos vienen por los sentidos ${ }^{70}$. Con todo, pensamos que Dios es increado, en el sentido de que no es creado por otro distinto de él, y, por lo mismo, está por encima de todos y a todos es trascendente, por lo que también no puede ser

69. Ibidem, I, 1; PL 122, 441-442.

70. Ibidem, I, 12; PL 122, 452 B-D. 
comprendido ni definido adecuadamente. Es Uno-Unidad, que se forma en tres sustancias:

1.- La ingénita: el Padre,

2.- la génita: el Hijo y

3.- la procedente de la ingénita y de la génita: el Espíritu Santo.

A Dios -lo mismo que en el Pseudo-dionisio- no se puede llegar directamente, sino a través de la vía de negaciones. Por lo que esta teología negativa adquiere con el Eriúgena suma importancia, que va pasar luego a la Edad Media posterior a él. Pero -parece- él también admite, en cierta manera, la teología positiva, al afirmar que Dios es la superesencia, la super-verdad y todo lo que, en grado sumo y eminente, se puede atribuir a Dios. Y así se convierte la teología positiva en negativa y la negativa en positiva. Porque, al afirmar que Dios es super-esencia, equivale a afirmar y negar al mismo tiempo que él sea esencia ${ }^{71}$. Por lo que Dios no es género, ni especie, ni accidente ni ninguna categoría del mundo creado ${ }^{72}$.

«El supera todo entendimiento y todo significado sensible e inteligible, de modo que se le conoce ignorándolo, y la ignorancia acerca de él es la verdadera sabiduría» ${ }^{73}$.

A pesar de todo, si Dios es inaccesible, como naturaleza superesencial, él se revela en la creación, que es una teofanía, o manifestación suya. La esencia divina, de por sí incomprensible, se manifiesta en las criaturas inteligentes, y hasta es posible conocerla en ellas. También una teofanía es el descenso de Dios al hombre a través de la gracia, para retornar luego, desde el hombre, a Dios por el amor. Cada una de las Tres Personas divinas tiene su propia teofanía: el Padre en la creación; el Hijo, creando las causas primordiales que subsisten en él universal y simplemente; el Espíritu Santo, multiplicando estas causas primordiales en sus efectos, es decir, distribuyéndolas en géneros y especies, números y diferencias, tanto de las cosas celestes como de las cosas sensibles ${ }^{74}$.

Dios es principio de todo, porque de él derivan todas las cosas y porque también participan de su esencia. Es el medio, porque en él se mantienen en el ser y actúan. Y es el fin, porque todas las cosas se dirigen-retornan a él, y en él buscan reposo y plenitud ${ }^{75}$.

71. Ibidem, I, 14; PL 122, 459 B.

72. Ibidem, I, 15; PL 122, 463 C.

73. Ibidem, I, 66; PL 122, $510 \mathrm{~B}$.

74. Ibidem, II, 22; PL 122, 563-566.

75. Ibidem, I, 1; PL 12, 441-442. 
Pero, ¿qué podemos decir del conocimiento de la esencia de Dios? Prácticamente nada adecuado, ya que supera todo conocimiento humano. Es la consecuencia de la teología negativa: sólo podemos saber lo que no es Dios, y decir de él lo que no es. En Dios se halla sublimado infinitamente todo, todo lo que aparece en los seres por él causados. Por lo que, para restablecer la verdad sobre él, hay que yuxtaponer a nuestra afirmación de la verdad simétrica, que nadie la contradice, porque es una negación que expresa una excelencia y no un defecto. Y por lo que, también, si decimos que Dios es esencia, tenemos que afirmar simultáneamente que él no es esencia. ¿De qué modo podemos entender esto? Quitando todo lo que en las esencias creadas no le conviene a Dios; por eso, no es esencia. Pero, como tampoco esto expresa la realidad de Dios, tenemos que proceder entonces a una tercera afirmación que nos dé simultáneamente la verdad de esos juicios fundados en un tercero y superior a los dos anteriores; y entonces diremos que Dios es superesencial, super-esse.

«¿No ves que estas cosas, es decir, la afirmación y la negación son contrarias recíprocamente?... Estas dos cosas, que parecen entre sí contrarias, no se oponen de ninguna manera en sí mismas, mientras se refieran a la naturaleza divina, porque, ante todo, están concordes consigo... La esencia es afirmación; la esencia nunca es rechazo. En la superior no hay negación; pero en el entendimiento está incluida la negación» ${ }^{76}$.

De la misma forma que decimos que Dios es ser, podemos decir también que no es ser, y proceder a la afirmación de que es super ser. Y de la misma manera decir que es super-verdad, super-bien...,

«porque él es el contorno de todo: de lo que es y no es, de lo que puede ser y de lo que no puede ser... Es la semejanza de lo semejante y de desemejanza de lo desemejante, la oposición de los opuestos, la contrariedad de los contrarios. Todo esto se une y forma en concordia por una bella e inefable armonía. Porque lo que parece opuesto en las partes de la totalidad y hasta contrarios y mutuamente distantes, son apropiados y concordes ${ }^{77}$.

En él están todas las cosas inmutables y esencialmente; él es la división y resumen universal de la criatura, mientras no sea el género, la especie, el todo y la parte de nada; pero todas estas cosas van, por sí y en sí, a sí mismo ${ }^{78}$.

Todo esto lo explica sirviéndose de las matemáticas. Por ejemplo, la unidad con relación al número, porque la unidad es el todo.

76. Ibidem, I, 14; PL 122, 459 B y C.

77. Ibidem, I, 72; PL 122, 517 B y C.

78. Ibidem, III, 1; PL 122, 621 C. 
«Supuesto que todos los números subsisten universal e inconmutablemente en la unidad, y que es la parte y el todo en todas las cosas y lo primordial de toda división, mientras sea ella misma en sí misma ni número ni parte suya... ${ }^{79}$

Más claro está en otro ejemplo, en el del punto con relación a la línea, en donde el punto es el comienzo y el fin de la misma, y en puntos la línea queda convertida. Lo mismo pasa con el centro en relación al círculo o con la esfera.

Dios es la unidad, unidad inefable, que no se cierra estérilmente en su singularidad, sino que se articula en tres sustancias: la ingénita del Padre, la génita del Hijo y la procedente de ambos, el Espíritu Santo. Siguiendo a los griegos, Eriúgena nos habla de tres sustancias al referirse a la Trinidad, en lugar de aludir a tres personas en una sola sustancia, como prefieren expresarse los occidentales ${ }^{80}$. Pero -nos parece- da al misterio trinitario un sentido panteísta. Dios es, en primer lugar, Padre; y como tal, sustancia de la que nace el Hijo y procede el Espíritu Santo ${ }^{81}$; pero, simultáneamente, es el desdoblamiento en el mundo de las ideas ejemplares o causas primordiales, y en este sentido es Verbo, Palabra, Ideas. Pero estas causas primordiales son sólo sus efectos, en el despliegue de la realidad cósmica, que es un acto de amor, que se extravierte al hacerse el mundo para retornar de nuevo a sí mismo. Y así, es vida, es Espíritu Santo.

«Pues, por lo mucho que los teólogos piensen que de tres maneras se realiza la operación divina, que todo lo ha construido -el Padre lo hace todo, todo se hace por el Hijo y por el Espíritu Santo todo se distribuye-, según la Sagrada Escritura, una sola operación se atribuye a la suma y santa Trinidad».82.

Podemos seguir concluyendo: Dios, en cuanto Padre, es decir, en cuanto que es causa causarum -causa de las causas-, no es otra cosa que eso: Causa suprema. $\mathrm{Y}$, por lo mismo, sería absurdo atribuirle un algo; $\mathrm{y}$, consiguientemente, no puede conocerse a sí mismo, sino en el Verbo; y amarse a sí mismo, sino a través del Espíritu Santo. Por lo que dice:

«Dios no sabe que es algo, porque no es algo».

$S u$ esencia es, justamente, ser la causa de toda esencia. Parece que el Eriúgena quiere dar a entender que la esencia divina no es, en última instan-

79. Ibidem, III, 1 ; PL 122, $621 \mathrm{C}$.

80. Ibidem, I, 16; PL 464 A.

81. Ibidem, II, 22; PL 122, 565 A.

82. Ibidem, III, 17; PL 122, 672 C y D. 
cia, sino el principio vital que pone continuamente y constantemente en movimiento su propia autocreación, la voluntad primera que decide expandirse $-\mathrm{y}$ de hecho se expande- en la creación de toda realidad: hacerse a sí mismo en el mundo:

«Se dice, por tanto, que en todo se hace la naturaleza divina, que no es otra cosa que la divina voluntad. Efectivamente, en ella no difieren el ser y el querer, de tal manera que, cuando se trata de establecer todo cuanto parece que ha de ser hecho, son una e idéntica cosa el querer y el ser» ${ }^{83}$.

Este pensamiento va a determinar el pensamiento de Ibn Gabirol, que, en su obra Fons vitae ${ }^{84}$, intenta salvar del panteísmo esta doctrina, afirmando, o preguntando más bien, ¿cómo es que se puede entender qué es la naturaleza divina, siendo nada existente? ¿Ella supera todo lo que existe, cuando ni el es ser, sino que de ella deviene todo el ser y supera toda esencia y sustancia con su energía? Dios no tiene consciencia de lo que es, porque si lo supiera, quedaría cerrado en sí mismo y a todo entendimiento. Todo cuanto es, desde el Verbo a la realidad contingente, no es sino una teofanía de Dios. Por tanto, se puede decir que se crea creando, ya que así se manifiesta y sólo así se conoce en esta manifestación, porque el mismo Dios es hacedor de todo y queda hecho en todas las cosas. Por lo mismo, dice:

«No me preocupa mucho mientras en los libros de los santos padres encuentro que han disertado muchas veces sobre la naturaleza divina, que ella no sólo es todas las cosas que existen, sino también el crear y ser creadas» ${ }^{85}$

"Así, la esencia divina, que existe por sí misma, supera todo entendimiento en lo que de sí y por sí en sí y para sí son hechas, lo que se llama crear" ${ }^{86}$.

La naturaleza divina se crea a sí misma en las cosas que ella misma crea, a la manera cómo nuestro entendimiento se crea a sí mismo en los pensamientos-juicios que formula y en las imágenes que recibe de los sentidos ${ }^{87}$. Por lo que para el Eriúgena conocer y hacer-crear es la misma cosa. Preguntamos: ¿de todo esto se puede colegir que el Eriúgena es panteísta? Así lo ve Amalrico de Bene, que da pie a la condena de la obra La división de la naturaleza por el papa Honorio III en el año 1225. Lo mismo quiere ver N. Abagnano en su Historia de la filosofía.

83. Ibidem, I, 12; PL 122, 453 D.

84. Ibidem, I, 12; PL 122, 452 A.

85. Ibidem, I, 12; PL 122, 453 C.

86. Ibidem, I, 12; PL 122, 453 C.

87. Ibidem, 1, 12; PL 122, 452-454. 
2.- Natura creans et creata = naturaleza que crea y es creada.

Es el segundo paso de la división, que nos huele a influencia del platonismo no superado. Dios constituye el mundo eterno y divino de las ideas y principios inmutables-ejemplares de la realidad cósmica sensible. Con lo que el mundo inteligible, emanado de Dios, es Dios mismo o naturaleza, el logos eterno, que es creado y creador.

La segunda naturaleza, que es creada y crea, es la segunda Persona de la Trinidad, el Verbo. En ella están todas las cosas que han sido creadas. Ahora se le presenta al Eriúgena esta pregunta: ¿qué valor causal tienen las formasideas subsistentes en el Verbo, si los cuerpos están formados por elementos que fueron creados de la nada? Si la nada es su verdadero origen, también ella hubiera sido la causa de los mismos. Y entonces la nada habría sido de condición mejor que las cosas de las que fue causa, porque la causa es siempre superior al efecto. ¿En qué quedamos? ¿La nada -que no es ser-es causa de todo lo cósmico? Para resolver esto el Eriúgena piensa que los elementos, que componen el mundo, no han sido creados de la nada, sino de las causas primordiales, que existen en el Verbo, y han estado siempre en el Verbo divino, porque las causas le son esenciales. La nada no encuentra asiento ni dentro ni fuera de Dios. Las causas han tenido comienzo con su creación, y antes de ésta no existían en las formas-ideas ni en las especies del mundo sensibles. La nada no encuentra asiento ni dentro ni fuera de Dios. Las causas han tenido comienzo con su creación, y antes de ésta no existían en las formas-ideas ni en las especies del mundo sensible. Pero también se puede decir que ya existían antes de su creación, porque subsisten en las causas primeras, que se contienen en el Verbo en el que no comienzan ni cesan de existir ${ }^{88}$. Por lo que la teofanía empieza con las causas primordiales. Y con relación a ellas, el Creador-Dios es creado por sí mismo y por sí mismo crea, es decir, comienza a manifiestarse, a salir de la profundidad de sí mismo y como comenzando a existir juntamente con ellas ${ }^{89}$. Por lo que podemos entrever, a lo largo de la obra del Eriúgena, la identidad esencial del criaturas-Creador, la permanencia de la criatura en la esencia del Creador, porque Dios las piensa y, por eso, son y son creadas ${ }^{90}$. Nosotros pensamos que el Eriúgena no cayó en la cuenta de la analogía aristotélica, que más tarde desarrollará santo Tomás de Aquino, para evitarnos confusiones.

88. Cfr. Canals Vidal, F: Historia de la filosofía, pág. 99: Ed. Herder, Barcelona, 1976.

89. De divisione naturae, III, 15; PL 122, $665 \mathrm{~B}$.

90. Ibidem, III, 23; PL 122, 688 D. 
Dios, cierto, precede al mundo, no en el tiempo, sino sólo en el campo lógico -estamos en el pensamiento del Eriúgena-, racionalmente, en cuanto es causa de él. Pero también dice Escoto Eriúgena que Dios no comienza a ser causa en un momento dado, porque él es causa esencialmente y no sería causa, si no creara el mundo; por lo que su creación debe ser eterna o coeterna con él ${ }^{91}$.

«Dios existía antes de crear todas las cosas» ${ }^{92}$

Si Dios es inaccesible como supra-esencia, super-ser, con todo, se revela a sí mismo en la creación, que es una constante teofanía:

«Dios, que es incomprensible en sí mismo, de algún modo se comprende en la Criatura» ${ }^{93}$.

Comenta Abagnano: la segunda naturaleza, la que es creada y crea, corresponde a la segunda Persona de la Trinidad. En ella están las ideas o formas de las cosas; y ella es, por lo tanto, el Verbo divino, a través del cual todas las cosas han sido creadas ${ }^{94}$, que es lo mismo que dice el Eriúgena:

«Fíjate cómo confiadamente pronunció que la naturaleza de todas las cosas, que han sido creadas, son el Verbo..., por ser-siendo, todas se hacen él mismo, porque todas son él mismo. Y para que más claramente conozcas al Verbo de Dios y que la naturaleza de todo es consustancial al Padre ante todo y en todo..." 95 .

Por otra parte, las causas primordiales no sólo fueron creadas en el Verbo, sino que son el mismo Verbo,

«todo lo que en el Verbo-Dios es sustancialmente, necesariamente es eterno, porque nada existe fuera del mismo Verbo» ${ }^{96}$.

Pero Escoto Eriúgena prefiere hablar, más que de ideas o formas, de causas, dando por supuesto que han de realizarse necesariamente, pues hace coincidir lo pensado por Dios con las posibles, a las que, de añadirse la vo-

91. Ibidem, III 8; PL 122, 639 B-C.

92. Ibidem, I, 72; PL 122, 517 C.

93. Ibidem, I, 10; PL 122, 451 B.

94. Abagnano, N: Historia de la filosofía, ya citada, págs. 272-273.

95. De divisione naturae, III, 21; PL 122, 685 C.

96. Ibidem, III, 9; PL 122, 642 A. 
luntad divina, se retornan en reales; y se hacen reales, porque Dios así las quiere. Piensa también que todo lo que existe estaba ya, de forma eminente, en esas causas primordiales; y si no las llama eternas, es porque son creadas, pero creadas desde siempre, porque subsisten como causas primeras en el Verbo divino -son el mismo Verbo divino-, en el cual no comienzan ni cesan nunca de existir. Pero están atravesadas por la negatividad de tener que existir-ser en el tiempo.

«Y por esto, no se puede comprender nada, cuando oímos que todas las cosas son creadas de la nada, sino porque él (Dios) existía, cuando no existían ellas. Por lo tanto, no sin razón decimos que siempre existían y que siempre no existían y que él no existían cuando ellas no existían; y, cuando ellas no existían, él existía. Aunque siempre estaban en el Verbo de manera causal, por energía y poder sobre todo espacio y tiempo, sobre toda generación local y temporalmente realizada, sobre toda forma y especie conocida por el sentido y el entendimiento, sobre cualquier otra cualidad y cantidad y sobre cualesquiera otros accidentes, por los que la sustancia de cualquier criatura, se entiende el existir, pero no lo que sea. Y siempre no existían; y antes, por la generación en formas y especies, lugares y tiempos y otros accidentes, que se llegan y vienen a la sustancia eterna de las mismas colocadas por debajo del Verbo inconmutablemente, no existían en su generación, ni existían en el tiempo y espacio, ni en sus propias formas y especies a las que se unen los accidentes» ${ }^{97}$.

La teofanía divina -aclara a Abagnano- empieza en las causas primeras, que subsisten en el Verbo. Para ella el mismo Creador es creado por sí mismo y por sí crea, es decir, empieza a aparecer en sus teofanías, a salir de las reconditeces de su existir justamente con ellas ${ }^{98}$.

Una doble manera ve el Eriúgena en el aparecer de las cosas en Dios como causas primordiales e ideas ejemplares, y entonces son Dios; y en cuanto concreciones espacio-temporales, y en este caso están en Dios sin dejar, por ello, de identificarse de alguna manera con él mismo.

«De una manera están en él, cuando aparecen visiblemente a través de la materia y son hechos por generación en género y formas, en lugares y tiempos; y de otra están en él, cuando se entiende que en las causas primordiales de las cosas, que no sólo se dan en Dios sino que también son Dios» ${ }^{99}$.

El Eriúgena vuelve una y otra vez sobre lo mismo: a su idea de la identidad de Dios con sus criaturas. El mundo es Dios mismo en su revelación; y, al igual que el mundo no puede existir sin Dios, Dios no puede existir sin el

97. Ibidem, III, 15; PL 122, 665 A y B.

98. Abagnano, N: Historia de la filosofía, pág. 317.

99. De divisione naturae, III, 8; PL 122, $640 \mathrm{C}$. 
mundo. Por lo que Juan Escoto Eriúgena afirma que Dios no existía antes de crear todas las cosas ${ }^{100}$.

«No otra cosa es ser para Dios y otra cosa hacer, sino que para él ser es ser él mismo y ser... Cuando oímos que Dios hace todas las cosas, no debemos entender más que Dios está en todo, es decir, que sostiene la sustancia de todo» ${ }^{101}$.

Y si Dios no es separable de la creación, Escoto puede decir que Dios, es sí mismo, antes de la creación nada era en realidad.

«Por lo tanto, no existía -erat- antes de hacer todas las cosas» ${ }^{102}$.

Es verdad, Dios precede al mundo, no en el tiempo, sino metafísicamente, porque él es su causa.

«Creemos que Dios precede-antecede a todo, no en el tiempo, sino por su sola razón, con lo que se comprende que él es causa de todo» ${ }^{103}$.

\section{3.- Natura non creans, sed creans = naturaleza que no crea y crea.}

Tercer paso de la división. La tercera naturaleza -que es creada y no es creadora- es el mundo: el conjunto universal de las cosas sensibles y no sensibles, pero que se derivan de las causas primordiales por la acción distribuidora y multiplicante del Espíritu Santo. Y piensa el Eriúgena que todo los cuerpos están compuestos-constituidos de materia y forma. Y nos da una opinión personal de la materia: ésta no tiene forma ni color, es invisible e incorpórea; y, por lo mismo, no es objeto apropiado de los sentidos, sino de la razón. Se constituye del conjunto de muchas y diversas cualidades, también incorpóreas, y se llega o transforma en los distintos y variados cuerpos a medida que se le añaden las formas y colores ${ }^{104}$.

Tampoco esta tercera naturaleza se distingue del Verbo, porque, pensándolo bien, la razón nos obliga a pensar que en el Verbo existen las causas primordiales y sus efectos. Por lo que en él también subsisten los lugares y

100. Ibidem, I, 72; PL 122, 517 A-D.

101. Ibidem, I, 72; PL 122, 518 A.

102. Ibidem, I, 72; PL 122, 516-518.

103. Ibidem, III, 8; PL 122, 639 B.

104. Ibidem, III, 14; PL 122; 662 C-D. 
los tiempos, las sustancias, los géneros y las especies y hasta los números o individuos con todas sus características cualitativas. Es decir, en el Verbo coexiste todo lo del universo de las cosas creadas, tanto del mundo sensible como del inteligible y hasta el angélico ${ }^{105}$.

El mundo es creado, y lo dice la Escritura; pero también es eterno, porque subsiste en el Verbo ab aternitate -desde siempre-, y lo confirma la razón. Pero la conciliación de que eternidad y creación se pueden compaginar en un misterio que la mente humana nunca podrá descifrar. Pero también dice el Eriúgena que este problema es más aparente que real, porque las cosas que se dan en el espacio-tiempo y están distribuidas en los géneros y en las formas del mundo sensible, no son en realidad distintas de las causas primordiales, que existen en Dios y son Dios mismo. El nos dice que no son dos sustancias diversas, sino dos modos distintos de entender la misma sustancia: en la eternidad del Verbo o en el transcurso del tiempo. Un ejemplo: no hay dos sustancias hombre, una como causa primordial y otra como especie y género en el mundo. En el hombre hay una sola sustancia, que se puede comprender de dos maneras: en su causa intelectual o en sus efectos creados. Entendida del primer modo, no está sujeta a mudanza; en el segundo modo, toda es mudable. En el primero escapa y está libre de sus cualidades accidentales; el segundo, que resulta de la composición de cualidades y cantidad, es susceptible de comprensión intelectual ${ }^{106}$. Siendo Dios el principio, el medio y el fin, todas las cosas salen de él y a él retornan. La Escritura habla del fin del mundo; y también es claro que todo lo que empieza a ser lo que antes no era, acabará por ser lo que es. Por consiguiente, si el principio de todo lo cósmico-mundano son las causas de las cuales el mundo ha aparecido a la existencia, estas mismas causas serán el último estadio de su retorno a Dios. El mundo no perecerá, sino que será devuelto a sus causas primigenias, es decir, al Verbo divino, que contiene esas mismas causas primeras. Y cuando el mundo en este retorno encuentre su fin, ahí mismo hallará su reposo ${ }^{107}$.

La naturaleza creada y no creadora es todo lo que es engendrado y existente en el tiempo, en particular el mundo de los cuerpos físicos. Al igual que las causas primeras era la teofanía de la esencia divina, el mundo-cosmos es la teofanía-manifestación de las causas primordiales; y si éstas se daban en el Hijo, la acción distribuidora y multiplicadora de las causas primordiales es obra del Espíritu Santo. Y aquí ya llegamos a la periferia de la realidad, a la zona de penumbra, que linda con el no-ser, con la nada absolu-

105. Ibidem, III, 16; PL 122, 666 B-C.

106. Ibidem, IV, 7; PL 122, 771 B-D.

107. Ibidem, V, 20; PL 122, 892 y sgtes. 
ta. El Eriúgena llama a estas criaturas participaciones. Y dice que participan inmediatamente de Dios. Las causas primordiales, pues, miran hacia arriba, hacia el principio último, hacia la esencia divina como causa de las causas; $y$ hacia abajo, hacia sus efectos múltiples, lo cual vincula la teoría del Eriúgena con la doctrina neoplatónica de la emanación. Dice también que la participación no es, en este caso, sino la derivación de una segunda esencia a partir de la esencia más elevada ${ }^{108}$. Concibe la esencia divina como una fuente de la que brota la realidad entera, como un río que se expande en todas las direcciones, dando origen, primero, a las causas primordiales y, posteriormente, y desde ellas, a sus efectos ${ }^{109}$. Nos encontramos con ejemplos neoplatónicos clásicos -el río, la fuente y la luz-, que hacen referencia clara a la emanación de Plotino. La verdad divina se derrama sobre el universo, de forma que

«hace todas las cosas y se hace en todas ellas y ella es también todas las cosas» ${ }^{110}$.

La corriente vital, que desciende desde la esencia divina, va diluyéndose y «cosificándose» en la medida que se aleja del centro y se aproxima a la periferia de las concreciones individuales, que lindan con la nocturnidad de la Nada absoluta; igual que en Plotino y que en la pirámide de Platón; los seres cuanto más alejados estén del Uno o del Bien, menos participan de las perfecciones de ellos.

Todos los objetos del entendimiento -conocimiento intelectual con las ideas incluidas- y de las sensaciones -conocimiento sensible-

«son la aparición de lo que no aparece, la manifestación de lo oculto, la afirmación de lo negado, la comprensión de lo incomprensible, la expresión de lo innegable, la aproximación de lo aproximable, el entendimiento de lo inteligible, el cuerpo de lo incorpóreo, la esencia de lo superesencial, la forma de lo informe» ${ }^{111}$.

De esta manera podemos decir que Dios crea todo de la nada, lo que es lo mismo que decir que él se manifiesta en ello.

Esta expresión de la nada quiere decirnos que Dios no tiene un quid; pero además significa la inefable, incomprensible e inaccesible claridad de la bondad divina, porque aquello que es comprensible, aquellos que excede

108. 47. Ibidem, III, 4; PL 122, 632-634.

109. Ibidem, III, 9; PL 645, C y sqtes.

110. Ibidem, III, 4; PL 122, 632-634.

111. Ibidem, III, 4, PL 122, 632-634. 
toda esencia puede ser llamado justamente por su excelencia nihilum, de forma que, cuando Dios comienza a aparecer en sus criaturas, a manifestarse y crearse en ellas, podemos decir que procede ex nihilo in aliquo ${ }^{112}$. Esto casi nos permite afirmar un ateísmo para el Eriúgena; pero, como podemos haber visto, esto está lejos de él.

Podemos hacer esta pregunta: ¿qué son los cuerpos y de qué está constituida la corporalidad? El Eriúgena afirma que todas las notas y categorías, que concretan la realidad en el espacio y en el tiempo, cuando se las considera en sí mismas, en su naturaleza, son realidades inteligibles y no corpóreas.

«Así, pues, las categorías incorporales son de por sí entendidad» ${ }^{113}$.

$\mathrm{Y}$ con esto caemos en un panlogismo. Pero cuando algunas de estas categorías, concretamente la cantidad, cualidad, el situs, el habitus, se unen entre sí constituyen la materia y la realidad sensible-física. Posiblemente esto lo retoma el Eriúgena de Gregorio de Nisa, a quien cita expresamente ${ }^{114}$.

También afirma que todos los cuerpos del mundo están constituidos de materia y forma, llegando incluso a afirmar que Dios es la forma de todas las $\cos ^{115}$. Pero esto no es propio de él -del Eriúgena-, porque los estoicos y Aristóteles habían ya dicho lo mismo. Pero más concreto el Eriúgena nos dice que es el Verbo el que constituye la forma del universo.

«De la forma de todo, es decir, del Unigénito Verbo del Padre, es creada toda forma, ya sea sustancial o que se tome de cualquiera otra cualidad y que se genera de la materia unida al cuerpo» ${ }^{116}$.

La materia, por estar falta de forma y color, es invisible e incorpórea; y, por lo tanto, objeto, no de los sentidos, sino de la razón.

«En verdad, la forma, que contiene la materia de los cuerpos, es incorpórea. La misma materia, pues, si uno se fija atentamente, se une a las cualidades incorpóreas» ${ }^{117}$.

Sólo si sólo se le añaden las formas, se transforma en los distintos cuerpos ${ }^{118}$. Por lo que el origen de los cuerpos es la conjunción de elementos primordiales.

112. Ibidem, III, 19; PL 122, 680-682.

113. Ibidem, I, 34; PL 122, 478-479.

114. Ibidem, I, 34; PL 122, 478-479.

115. Ibidem, I 34; PL 122, 479 A-C.

116. Ibidem, I 59; PL 122, 501-502.

117. Ibidem, I, 42; PL 122, 484 D.

118. Ibidem, III, 14; PL 122, 662 C. 
"Ciertamente los cuerpos nacen de las cosas incorporales» ${ }^{119}$.

La materia y Dios, que es su forma, son indefinibles ${ }^{120}$. También llega a afirmar que los cuatro elementos -agua, tierra, fuego y aire-, de los que están compuestos los cuerpos ${ }^{121}$, subsistían en las causas primordiales.

"Me veo obligado a confesar que los elementos de este mundo subsisten en las causas primordiales» 122 .

Comentando este tema, N. Abagnano dice que tampoco la tercera naturaleza -el mundo- se distingue en realidad del Verbo. La Razón -según Eriúgena- no obliga a reconocer que en el Verbo subsisten, no sólo las primeras causas, sino también sus efectos; y así están en él los lugares y los tiempos, las sustancias, los géneros y las especies, hasta las especies especialísimas, representadas por los individuos con todas sus cualidades naturales ${ }^{123}$.

Pero, si esto es así, tal como se desprende de la palabras del Eriúgena, el cosmos no sería un proceso, tal y como nos lo muestra la experiencia, sino que tendríamos una realidad eterna, necesaria, inmutable, y la imagen de Dios se disolvería en la pluralidad del universo. El mismo Eriúgena nos da la solución, inspirado en un texto de San Agustín, al decir:

«Todo lo que es y no es lo digo, no como falta-privación, sino según la superioridad con que está comprendido en el Verbo» ${ }^{124}$.

Es decir, todas las cosas se dan en el Verbo de un modo excelente-superior, o lo que es lo mismo, sin la privatio que supone su realización en el espacio-tiempo, en donde la realidad ideal es negada dialécticamente, pues se da a un nivel inferior en el campo de lo temporal y contingente. Doble forma de ser que el Eriúgena expone de una manera muy clara:

«Por la misma razón se dice que ahora son, y son siempre y verdaderamente serán en cuanto que subsisten en sus causas. En cuanto a los accidentes, que se les llegan extrínsecamente, se dicen ser; sin embargo, verdaderamente no son ni siempre son» ${ }^{125}$.

119. Ibidem, III, 14; PL 122, 663 A.

120. Ibidem, I, 56; PL 122, 499 D.

121. Ibidem, I, 34; PL 122, 479 A-C.

122. Ibidem, III, 14; PL 122, 663 A-D,

123. Abganano, N: obra citada, pág, 318.

124. De divisiones naturae, III, 16; PL 122, $667 \mathrm{~A}$.

125. Ibidem, III, 15; PL 122, 665 D; 666 A. 
Esto lo tiene él muy claro, nosotros no tanto. Por lo que dice también que una parte del todo subsiste como eterna en el Verbo de Dios y otra parte ha sido hecha temporalmente fuera Verbo ${ }^{126}$. Y para aclarar todo esto recurre a una expresión muy significativa : vis seminalis incorporea. Esta, al igual que energía seminal corpórea, hace germinar la realidad de las causas seminales en su momento oportuno y conforme al modelo que en ella está tipificado. Todas las cosas, pues, están desde la eternidad en el Verbo divino; pero se van manifestando en el tiempo, pasando de la pura esencia a la existencia espacio-temporal, según los módulos del proyecto divino.

«La constitución de las naturalezas «empieza» con recibir en el tiempo y por generación las cantidades y cualidades, en las que se manifiesta como arropada con sus vestidos-coberturas, porque existe y no por lo que sea. Pues comienza a ser de alguna manera, no en cuanto subsiste en las causas primordiales, sino empieza a aparecer por las causas temporales» ${ }^{127}$.

De esta forma, la realidad, que es sustancialmente espiritual, se viste de maternidad y permite su percepción por los sentidos:

«...Pues si los cuerpos no se perciben con los sentidos, no son cuerpos» ${ }^{128}$.

Lo que añade la corporalidad a la realidad es, precisamente, el poder ser percibida por los sentidos, según el Eriúgena.

\section{Natura nec creata nec creans = la naturaleza que no crea ni es creada.}

Es la última etapa del proceso dialéctico de la división de la naturaleza. Todo sale de esa naturaleza increada y que es creadora, pero que se manifiesta y se crea en todas las cosas. Todo tenderá al origen fontal de donde salieron. Y así la naturaleza entera pueda centrarse en el todo único indiviso e inmutable que, por ser el principio, medio y fin, es increado y no creado, porque, precisamente, Dios es la totalidad de las cosas. Y así será Dios todo en todas las cosas cuando no habrá nada sino Dios solo ${ }^{129}$.

¿Se podrá decir que el Eriúgena afirma una división total? A primera vista su obra La división de la naturaleza se constituye sobre una dinámica conceptual de lo eterno y necesario retorno, «como un momento eternamen-

126. Ibidem, III, 15-16; PL 122,665 C-D.

127. Ibidem, III, 15; PL 122, 665 C.

128. Ibidem, I, 34; PL 122, 479 A.

129. Ibidem, V, 8; PL 11, 876 B. 
te exigido, no como consecuencia del pecado, sino por el proceso de emanación y retorno del universo a Dios» ${ }^{130}$.

Por consiguiente, Dios se constituye en el único, en el increado no creador a través de la divinización. Si la división lleva el proceso dialéctico a la expansión cósmica hasta los linderos de la Nada absoluta y con ello culmina la esfera de lo real. El análisis o recapitualción es el proceso de regreso, el retorno de todas las cosas a la casa del Padre - $i$ descenso y ascenso plotiniano?-. Esto está fundado en Escoto Eriúgena en un principio qu eél considera evidente.

«El final de todo movimiento es el principio de sí mismo. No se termina en otro final, sino en su propio comienzo desde el que comienza a moverse y al que siempre desean volver para que se termine y descanse en él. Y esto no sólo se refiere a las partes del mundo sensible, sino que todo esto hay que referirlo a él mismo. El fin es el principio de sí mismo, que es lo que desea; y, cubierto este deseo, cesará, no como que pereciera la sustancia de sí mismo, sino que se reintegra a sus razones de las que salió» ${ }^{131}$.

Este movimiento de restauración es obra simultánea de la naturaleza y de la gracia, que pueden ser llamadas, con relación a Dios, destino y donatio respectivamente. Todo ser tiene programado su itinerario de ida y de retorno como un «destino»-y esto desde siempre-, que es al mismo tiempo un regalo gracioso de Dios; porque todo termina bien en esta inmensa epopeya en que se expresa el sistema filosófico-teológico del Eriúgena. A ninguna naturaleza le es permitido quedarse en la nada, perderse en ella, sino que donde alcanza su ruina allá mismo comienza su retorno ${ }^{132}$.

Existe una tendencia del no-ser para alcanzar el ser, lo que se llama informitas. Esto es como un deseo ontológico de todas las criaturas de retornar al seno divino de donde salieron. La informidad se define como un cierto movimiento hacia el ser. Bajo la acción de este impulso oscuro el tropel de los seres es como un río que, después de perderse en las arenas, volviera a sus fuentes por los poros secretos del suelo ${ }^{133}$. Este proceso se realiza gracias, justamente, a la negatividad, al igual que el primero: la realidad contingente es negada, pero no pasa con ello al no-ser, sino que retorna y se sublima en la realidad superior ${ }^{134}$. De esta forma

130. Cfr. Canals Vidal, F: Obra antes citada, pág. 102.

131. De divisione naturae, V, 3; PL 122, 866 C-D.

132. Ibidem, V, 7; PL 122, 874-876.

133. Ibidem, III, 4; PL 122, 632-634. 
«el fin de sí mismo es su propio principio, al que apetece; y, una vez descubierto este deseo, cesará, no como que perezca la sustancia propia, sino en sus razones de las que salió» ${ }^{135}$.

Después de todo esto se producirá el eterno silencio, la quietud infinita.

«Todo quedará imóvil en sí mismo cuando todo regrese a sus razones inmutables» 136 .

Dios permanecerá en el recuerdo nostálgico de la gran aventura de su teofanía cósmica. Será un proceso de plenitud donde ya Dios no es un quid incognitum, porque su esencia se hace patente. Será todo esto como un retorno de las criaturas al seno materno, a las semillas primeras, un trnasformarse los pensamientos divinos de sueños en recuerdos; y todas las cosas dormirán en reposo infinito, iluminadas por la transformadora luz de su divinización,

«... porque ya deja de crear todas las cosas, y quedarán vueltas todas a sus razones eternas... Dios será todo en todas las cosas y toda criatura será iluminada, es decir, vuelta a Dios como las estrellas por el sol naciente» ${ }^{137}$.

Este fin de todo será una divinización universal -theosis- de todas las cosas, que, con esto, no perderán su propia identidad. Todas las criaturas se juntarán al Creador y serán uno con él. Y este es el final de todo lo visible e invisible. Porque todas ellas pasarán hacia Dios por una admirable e inefable reunión, sin confundirse ni perder nada de lo suyo, ni en la esencia ni n la sustancia ${ }^{138}$.

Este retorno o reintegración supone que nada quedará en la nocturnidad de la materia, nada de maldad o contingencia. Todo será purificado y asumido por la esencia divina. Los condenados, y hasta el mismo diablo, volverán al hogar purificados ${ }^{139}$, y ser harán luz divina ${ }^{140}$.

\section{VI.- EL HOMBRE}

El hombre es parte de esa naturaleza que es creada y no crea. El Eriúgena dedica al hombre todo un tratado, que trataremos de resumir, el tratado cuarto. Por lo que el Eriúgena se hace estas preguntas sobre el hombre:

135. Ibidem, V, 3; PL 122, 866 D.

136. Ibidem, I, 30; PL 122, 476 B.

137. Ibidem, I, 23; PL 122, 689 A.

138. Ibidem, V, 12-13; PL 122, 883-885.

139. Ibidem, V, 27; PL 122, 921-931.

140. Ibidem, V, 39; PL 122, 1019-1029. 
1.- ¿Qué somos los hombres?

2.- ¿Qué es lo nuestro?

3.- ¿Qué hay en el entorno nuestro?

A la primera pregunta contesta: No somos sustancia nuestra, aunque sea vital e inteligible y que está sobre el cuerpo y sobre toda forma visible... A la segunda: Lo nuestro, no nosotros, es cuerpo que se nos pega, compuesto de cantidad y calidad y de otros accidentes; es sensible, mudable, soluble, corruptible; y no se puede decir otra cosa sino que es instrumento y asiento de los sentidos... A la tercera: Junto a nosotros están todas las cosas sensibles, que usamos... Pues, los cuerpos mortales no pueden existir sin todo esto ${ }^{141}$.

Tiene el Eriúgena en Platón un maestro en su doctrina sobre el hombre. Para los dos el hombre es sólo alma, siendo su cuerpo un soporte y una cárcel. Por otra parte, con San Agustín, a quien acude muchas veces, piensa que el hombre es imagen de Dios.

«Parece que existen dos naturalezas, con las que nuestra naturaleza se prueba que subsiste en cuanto que está hecha a imagen de Dios» ${ }^{142}$.

Las tres divinas personas de la Trinidad se relacionan entre sí como esencia -ousía-, como potencia -dynamis-y acto-energeia-. En el alma humana la esencia es la inteligencia -nous-, que es la parte más elevada de nuestra naturaleza. La razón -logos- corresponde a la virtud-energía o dynamis; el sentido inferior -dianoeia-corresponde al acto o energeia y se ocupa de los efectos. Estas tres partes constituyen una unidad sustancial, eterna e inseparable:

«.. las tres son inseparables e incorruptiblemente permanentes... y no se pueden separar la una de las otras» ${ }^{143}$.

El sentido interior es coesencial con la razón y el entendimiento, mientras que el sentido exterior, que se sirve de los cinco órganos, pertenece al cuerpo, más que al alma, de forma que perece con la disolución de aquel ${ }^{144}$.

La relación entre alma y cuerpo -y aquí existe una contradicción con lo dicho antes- es semejante a la existente entre la esencia divina y el mundo. Y, como Dios es cognoscible a través de las criaturas, pero incomprensible

141. Ibidem, I, 54; PL 122, 497-498 A.

142. Ibidem, II 23; PL 122, $570 \mathrm{~A}$.

143. Ibidem, I, 44; PL 122, 486 C y D.

144. I, 23; PL 122, 569-570 A-D. 
en sí mismo, ya que ni él mismo puede entender lo que es, pues no tiene un quid, una esencia determinada que se puede conocer, del mismo modo el alma sabe que es, pero no sabe qué es ${ }^{145}$.

Con alusiones agustinianas la metafísica del Eriúgena está impreganada de la línea del neoplatonismo de Plotino. Por lo demás, la naturaleza humana ha sido creada y con ella unidad de la totalidad de la creación sensible:

«La naturaleza humana es total en la univrsalidad de toda la naturaleza creada, porque en ella ha sido creada toda naturaleza, y por la misma ha sido toda criatura unida, y en el hombre tiene que volver toda naturaleza y por él tiene que ser todo salvado» ${ }^{146}$.

\section{Definición del hombre}

El Eriúgena nos da una definición del hombre en conformidad con su pensamiento, y dice:

«Podemos definir al hombre de esta manera: el hombre es una cierta noción intelectual hecha eternamente en la mente divina».

Toda otra definición, como decir que el hombre es animal racional, mortal, capaz de sentir, etc., no es una definición sustancial, sino superficial ${ }^{147}$. No tiene el hombre otra sustancia que su noción en la mente de su creador, que antes de que nada suceda, lo conoce todo en sí mismo ${ }^{148}$. Luego el hombre tiene un argumento, cuando viene al mundo, para explicar lo que desde toda la eternidad ya estaba allí presente desde siempre.

Si en relación con Dios está en ser copia o imagen suya, con relación al resto del mundo de la creación, el hombre ocupa un lugar de privilegio. Por toda la obra del Eriúgena circula este sentido de superioridad del hombre sobre la universalidad de los seres creados, y hasta parece que éstos tienen un sentido de exaltación del hombre hacia lo divino. Lo califica como término medio - medietas- de todas las criaturas, su unión -adunatio-, su conclusión -conclusio-, su lugar de fabricación -officina- y hasta lo llama micro$\operatorname{cosmos}^{149}$, término que se usará ya en toda la Edad Media para expresar la especial dignidad del hombre. Y todo, porque Juan Eriúgena piensa que el

145. Ibidem, IV, 7; PL 122, 638 D.

146. Ibidem, IV, 7; PL 122, 768 B-D.

148. Ibidem, IV, 7; PL 122, 768 y sgtes.

149. Ibidem, V, 21; PL 122, 877-898. 
hombre es una especie de síntesis de la naturaleza creada: porque en él se contiene toda la criatura ${ }^{150}$.

«Por esto, no sin razón se llama al hombre «fabrica»-taller de «todas las cosas», porque en él se contiene toda criatura. Ciertamente entiende como el ángel, razona como hombre, siente con el animal irracional, vive como semilla, se compone de alma y cuerpo y no está deprovisto de lo de ninguna criatura. Fuera de su naturaleza no encuentras criatura alguna» ${ }^{151}$.

Aún más. Llega a afirmar que Dios «hizo toda criatura visible e invisible en el hombre, porque en él subsiste el universo entero» ${ }^{152}$.

“Todo este mundo sensible fue edificado en él (en el hombre); pues, no se encuentra ninguna parte suya (del mundo), sea corpórea o incorpórea, que no subsista creada que sienta, viva y sea incorporada en el hombre..., porque Dios quiso crear en él a toda otra criatura» ${ }^{153}$.

¿Qué entiende el Eriúgena por crear todas las cosas en el hombre? Sencillamente, defiende que las sustancias de todas se dan en la sustancia del hombre, y que él, por lo mismo, resume la sustancia; y, lógicamente, él posee todas esas nociones, porque en él radica la sustancia de las mismas, ya que esas cosas no se poseen a sí mismas, porque no tienen consciencia de su propio ser. Y, partiendo del texto bíblico del Génesis, en donde se ve a Adán imponiendo nombre a todos los seres vivientes, dice:

«Todo lo que él nombre, ése es su nombre; es decir, él es la noción del alma viviente. ¿Qué extraño es que se entienda como sustancia, si la noción de las cosas, que posee el alma humana cuando se creó en ella y de la que es su noción, si se parece a la mente divina, en la creación de la totalidad creada es sustancia de su totalidad incomunicable...? ${ }^{154}$.

Fueron creadas todas las cosas en el hombre ${ }^{155}$, porque sólo el hombre posee el conocimiento de todas ellas, y el concepto es justamente la sustancia de lo real. De aquí que, con su pecado, el hombre mancha de una forma sustancial toda la realidad y, con su redención, el mundo entero se redime ${ }^{156}$. Son muy significativas las consideraciones que Escoto hace sobre el futurible

150. IIbidem, IV, 5; PL 122, 634-637.

151. Ibidem, III, 37; PL 122, 733 B.

152. Ibidem, IV, 7; PL 122, 764 A y B.

153. Ibidem, IV, 7; PL 122, 764 A y B.

154. Ibidem, IV, 7; PL 122, 764 A.

155. Ibidem, IV, 8; PL 122, 772-775.

156. Ibidem, IV, 7; PL 122, 764 A-D. 
de que si el hombre no hubiera pecado, éste sería omnipotente como Dios: nada le apartaría del modelo divino, del que es su imagen ${ }^{157}$.

Llevado por el mismo optimismo, analiza también el destino último del hombre, que no es otro que su idenidad con Dios, su deificatio, como él lo llama ${ }^{158}$.

El proceso dialéctico de la divisio empieza en el hombre y en él termina ${ }^{159}$.

«... La reunión de todas las sustancias empieza en el hombre y por el hombre sube hasta Dios, que es el principio de toda división y el término de toda reunión...» ${ }^{160}$.

La muerte marca, precisamente, en el hombre el punto extremo de su alejamiento, de su nihilación, y el principio del retorno, el comienzo de una ascensión que le lleva a la identificación con el mismo Dios-sustancia ${ }^{161}$. El retorno comienza con la resurrección de los cuerpos -sin distinción de sexos, que el Eriúgna atribuye al pecado-, su transformación en ser espiritual, su integración en el Verbo y la divinización de todo hombre. Entonces ya no habrá más que Dios, que será todo en todo ${ }^{162}$. Sin embargo, él piensa que esta vuelta al seno de Dios no será una anulación en un místico disolverse panteísta, sino que el hombre permanecerá en su verdadera sustancia, aunque atravesada por lo divino, como el aire que se hace luz sin dejar de ser aire.

«Con esto no se intenta afirmar una sustancia perecedera de las cosas, sino un regreso a algo mejor a través de los grados antedichos. ¿Cómo puede perecer lo que, según se prueba, se convierte en mejor? Hay que pensar, por lo tanto, que el cambio de la naturaleza humana en Dios no es pérdida de sustancia, sino una vuelta, maravillosa e inefable, al primer estado, que perdió por el pecado" 163 .

\section{VII.- HOMBRE Y CONOCIMIENTO}

Para San Agustín el hombre interior es imagen de la trinidad. El Eriúgena retoma este pensamiento agustiniano para su cuerpo de doctrina sobre el

157. Ibidem, IV, 7; PL 122, 776 A-D.

158. Ibidem, V, 38; PL 122, 1014-1015.

159. Ibidem, I, 4; PL 122, 444 A-C.

160. Ibidem, II, 5; PL 122, 531-532 D-A.

161. Ibidem, V, 7; PL 122, 874 C-D.

162. Ibidem, V, 8; Pl 122, $876 \mathrm{~B}$.

163. Ibidem, V, 8; PL 122, 876 B. 
hombre; y lo explica a su manera: las tres Personas de la Trinidad están entre sí como ousía-esencia, como dynamis-potencia y como acto-energeia. Algo parecido sucede en el alma humana. La esencia es la inteligencia o nous, que corresponde a la parte más superior de nuestro ser y que es la que entiendeconoce a Dios y a las causas primordiales del mundo. La razón o logos corresponde a la potencia-virtus-dynamis, y que se encarga de distinguir los principios-orígenes de las cosas que vienen en escala descendente desde Dios. El sentido interior o dianoia corresponde al acto o energeia, y su cometido es hacer que apreciemos los efectos, sean visibles o invisibles, de las causas primordiales o primeras. Este sentido interior es propio de la razón y del entendimiento. El sentido exterior, propio de los órganos de los cinco sentidos, reside en el corazón y pertenece más al cuerpo que al alma y desaparece con la muerte del cuerpo ${ }^{164}$.

A estas tres partes del hombre les corresponden otros tres movimientos; según el alma, según la razón y según el sentido. El primero de los movimientos es el que, mediante el cual, el alma se mueve hacia Dios, subiéndose por encima de sí misma y de toda criatura. Por lo que el alma aquí se muestra trascendente a todo lo creado y como absolutamente indefinible. El segundo movimiento es el que y por el cual el alma entiende al Dios desconocido como causa de todo, ya que en Dios existen las causas primordialesprimeras. En el tercer movimiento el alma encuentra las razones de las cosas individuales. Este movimiento eleva al alma, desde las imágnes recogidas por los sentidos externos, hasta las razones últimas de las cosas de las que las cosas mismas son imágenes. En este movimiento, por lo tanto, la imagen sensible queda transfigurada: de imagen impresa en los sentidos se cambia en imagen que el alma siente como algo propio. $\mathrm{Y}$, por esta razón también ella sube hasta las razones eternas de las cosas ${ }^{165}$.

La relación entre el alma y Dios se traslada también a lo referente al conocimiento que el alma tiene de sí misma. Y así como Dios es conocido a través de las criaturas, quedando incomprensible en sí mismo, porque él ni otro alguno puede entender lo que es, pues no tiene un quid-algo, una esencia determinada para entender ${ }^{166}$, lo mismo el alma, si sabe que es-existe, no puede conocer qué es. Y esto, que pudiera entenderse como un límite o dificultad de la mente humana, no es tampoco imperfección; sigue la línea de la inteligibilidad de Dios. Y también como la mejor manera de subir hasta Dios no es la afirmación -teología positiva-, sino la negación -teología negativa-,

164. Ibidem, II, 23; PL 122, 567-578.

165. Ibidem, II, 23; PL 122, 569-570.

166. Ibidem, II, 28; PL 122, 587-588. 
porque Dios no puede ser definido, porque no tiene límites, -y la afirmación se enmarca en los límites-, por eso, no se puede reducir a una esencia determinada. Por lo tanto, si fuera posible al alma conocer su propia esencia, esto sería dar por supuesta la posibilidad de encerrarla en una definición circunscriptiva e implicaría su disconformidad con el Creador ${ }^{167}$.

\section{VIII.- EL HOMBRE, ¿ALGO DIVINO?}

En todos los escritos del Eríguena puede verse la calidad superior del hombre sobre toda la creación, casi como un ser divino. El Eriúgena -creemos- reacciona contra todo el pesimismo de los siglos anteriores, hasta sublimar al hombre en sus propias capacidades.

«Por esto, no sin razón se llama al hombre fábrica-taller de todas las cosas, porque en él toda criatura se contiene. Ciertamente entiende como el ángel, razona como hombre, siente con el animal irracional, vive como semilla, se compone de alma y cuerpo y no está desprovisto de lo de ninguna criatura. Fuera de su naturaleza no encuentra criatura alguna» ${ }^{168}$.

Y en cierto modo es superior al ángel, porque éste carece de cuerpo y no tiene sensibilidad ni movimiento vital ${ }^{169}$.

¿Qué hubiera pasado, si no hubiera pecado el hombre? También este tema entra en el pensamiento del Eriúgena. Si el hombre no hubiera pecado, sería casi omnipotente, como casi Dios. Porque nada lo hubiera apartado de Dios; y él, que es su imagen, participaría de lleno en la perfección divina, porque en su resplandor-imagen. Por el mismo motivo sería también omnisciente; porque, como Dios, conocería las causas primordiales de todo lo creado en el cosmos, y todo el cosmos. Y también, si el hombre no hubiera pecado, su semejanza con la naturaleza angélica se hubiera transformado en identidad, por la que el ángel y el hombre serían una misma cosas. Y lo explica aclarando por la identidad que hay entre hombre y hombre.

«Nosotros, cuando dialogamos, nos hacemos íntimamente. Pues, es verdad, cuando entiendo lo que tú me entiendes, me hago entendimiento tuyo, y, de una cierta manera maravillosa me he hecho en ti. Del mismo modo, cuando entiendes claramente lo que yo, te haces entendimiento mío; y de dos entendimientos se hace uno solo, formado por aquel que entendemos sinceramente y

167. Ibidem, IV, 7; PL, 122, 762-763.

168. Ibidem, III, 37; PL 122, 733 B.

169. Ibidem, III, 37; PL 122, 732-733. 
sin vacilación. Pongamos un ejemplo en los números: sabes que el número seis es iugal en todas sus partes. Pues, yo comprendo de la misma manera; y entiendo que te entiendo como tú comprendes que lo entiendo. Nuestros dos entendimientos se hacen uno solo formados con seis números; y, por eso, yo me creo en ti y tú te creas en mí, pues, no somos nosotros una cosa y nuestro entendimiento otra. Ciertamente nuestra esencia verdadera y suma es el entendimiento visto a través y por la contemplación» ${ }^{170}$.

El Eriúgena tiene una alta concepción sobre el hombre que casi lo diviniza y que ni casi el pecado original ha sido suficiente para destruirla. No se destruyó la naturaleza humana con el pecado, porque ella es indestructible, sino que perdió la felicidad, que era su destino, desobedeciendo al mandato del Señor.

«Era necesario entender que la naturaleza humana, que está hecha a imagen de Dios, no perdió nunca la fuerza de su belleza, ni la integridad de su esencia, y nunca puede perderlas. Una forma divina, como es el alma, permenece siempre incorruptible; a lo sumo se convierte en un ser capaz de soportar el pecado» ${ }^{171}$.

También habla el Eriúgena del destino del hombre, y lo hace con una visión optimista. Su muerte es el comienzo del regreso-ascensión, que le lleva a identificarse-fundirse en Dios. Por lo que la muerte, en realidad, no existe y sí el retorno al antiguo estado, que tuvo antes de cometer el pecado. Nos da cinco fases para este retorno-ascensión:

1.- la primera se realiza cuando se le descomponen los cuatro elementos de que consta su cuerpo;

2.- la segunda es la resurrección en que cada uno recibirá a su cuerpo al juntarse nuevamente los cuatro elementos;

3.- la tercera, el cuerpo se transforma en espíritu;

4.- en la cuarta la naturaleza humana retornará a sus causas primordiales, que existen en Dios, y la

5.- la naturaleza humana, junto con sus causas, se irá a Dios, como el aire se mueve en la luz ${ }^{172}$

El triunfo de la naturaleza humana no será nunca una anulación de Dios, porque no se puede entender en el Eriúgena un disolverse místicopanteísta del hombre en Dios. No se puede comprender tampoco el destino de la naturaleza humana como un perderse-fundirse en el ser divino, sino

170. Ibidem, IV, 9; PL 122, 780 C-D.

171. Ibidem, V, 6; PL , 122, 872 A.

172. Ibidem, V, 8; PL 122, 876 A-B. 
sólo como el permanecer en su verdadera sustancia, al integrarla a sus causas primeras y de mantenerse en su perfección completa en el ámbito de lo divino. Por lo que Escoto corrige al misticismo neoplatónico al fundamentar el sentido de carácter irreductible de la naturaleza humana con la que, aún frente a Dios, conserva su autonomía sustancial.

\section{IX.- MAL Y LIBERTAD}

Parece que el Eriúgena parte del concepto del mal que tiene los neoplatónicos y el mismo San Agustín, al enunciar éstos que el mal no es una realidad, sino una ausencia de realidad, o una negación de algo real debido. Por esto afirma que Dios no conoce el mal, porque el conocimiento divino es inmediatamente creador. Todo lo que es, es pensamiento divino; y lo que no es, Dios no lo conoce ni lo ha pensado. De lo que se sigue que, si Dios conociera el mal, éste sería una realidad en el mundo ${ }^{173}$. Por lo tanto, el mal no es algo real; no es nada sustancial, por lo que las apariencias seductoras, que se presentan al hombre malvado, son nada en sí mismas. Un objeto precioso, bello, que seduce la ambición del avaro, en el sabio inspira admiración desinteresada. Por lo tanto, no es la apariencia bella la que hace pecar al hombre, sino la mala disposición-uso que el hombre hace de ella ${ }^{174}$.

¿Qué es, pues, la libertad humana? La posibilidad de pecar o no pecar, porque sólo esta posibilidad hace que el hombre pueda ser premiado o castigado según el jucio de Dios. Y puesto que quien peca sólo él puede ser castigado, en el hombre pecador sólo se castiga su mala voluntad-libre-albedrío, porque ella sola es la responsable de los actos humanos, y sólo ella será castigada por Dios. Y así, deja íntegra y salvada la naturaleza humana del pecador, que puede volver a a Dios en el triunfo final ${ }^{175}$. A que consiga el hombre este triunfo final se le yuda con su naturaleza el haber sido sacado de la nada; y su durar-permanecer en la misma, a la gracia de Dios-deificatio-por medio de la cual vuelve a la sustancia divina. La naturaleza le es debida al hombre por ser hombre; pero la gracia es un don gratuito -regalo-, concedido por Dios sin mérito alguno por parte del hombre.

«El mal, ciertamente, es incierto e incausal, porque no se encuentra sustancialmente de ninguna manera en la naturaleza de las cosas. Pues aquel leño, en cuanto malo, no se refiere a ninguna causa, porque (el mal) es absolutamente nada» ${ }^{176}$.

173. Ibidem, II, 28; PL 122, 596 B.

174. Ibidem, IV, 16; PL 122, 822 B-C; 824, B-C; 827 A-D.

175. Ibidem, V, 31; PL 122, 941-948.

176. Ibidem, IV, 16; PL 122, 828 A. 
Y argumenta. Si el mal moral se atribuye a la naturaleza, lo estamos también atribuyendo al autor de la misma. Es decir a Dios.

«Si la causa de la culpa se atribuye a la naturaleza, a la misma causa de la naturaleza, que es Dios, el pecado necesariamente se atribuye a la naturaleza. Pero la naturaleza ha sido creada a la imagen de Dios, no es completamente semejante a su principal modelo si recibe en sí misma la causa de pecar» ${ }^{177}$.

Luego no queda otro camino que atribuir el mal al uso incorrecto de los bienes naturales por un uso irracional de los bienes racionales ${ }^{178}$ al mal uso de la libertad-libre-albedrío contra las leyes divinas ${ }^{179}$.

Ahora bien, como el ser sustancial de toda realidad es el que Dios tiene de ella ${ }^{180}$, necesariamente Dios no puede conocer el mal; y si Dios no lo conoce, el mal no existe como sustancia. Porque Dios no conoce las cosas que son, sino que las cosas son en la medida que Dios las conoce; o mejor, las piensa y, al pensarlas, las crea. Todo lo que es, es pensamiento divino. Por lo que se ve que, si Dios conociera el mal, éste tendría una realidad. Pero el mal sólo es negación.

«Solamente él (Dios) es el bien sustancial por sí mismo. Todos los otros son tales por la participación en él. Por lo tanto, Dios desconoce el mal; porque, si lo conociera, necesariamente existiría el mal en la naturaleza de las cosas. La ciencia divina es causa de todo lo que existe. Dios no conoce las cosas que existen, sino que las cosas existen porque Dios las conoce...» ${ }^{181}$.

Y si esto es así, sólo puede haber una predestinción para el bien, porque todo lo que está implantado en la naturaleza es bueno ${ }^{182}$.

La pena que recae sobre el pecado tampoco consiste en una realidad positiva, y, por ella, sólo tiene responsabilidad la causa eficiente del mismo. La pena sí que es consecuencia del pecado, y le sigue como si estuviera amarrada a él. Pero ni la pena ni el pecado tienen cabida en la mente divina en la que sólo se puede asentar el bien ${ }^{183}$. De esta forma lo que Dios castiga no es su obra, sino el defecto que comete su obra:

«Por este motivo se comprende rectamente y se cree con verdad que Dios no castiga a ninguna naturaleza por él creada, sino sólo lo que él no ha hecho ${ }^{184}$.

177. Ibidem, V, 36; PL 122, 974 A y B.

178. Ibidem, V, 36; PL 122, 974 A.

179. Ibidem, V, 36; PL 122, 974 A y 975 B.

180. Ibidem, IV, 7; PL 122, 765 A.

181. Ibidem, II, 28; PL 122, 596 A-B.

182. Ibidem, V, 7; PL 122, 874 D.

183. De praedestinatione, XV, 9; PL 122, 416-417.

184. De division naturae, V, 35, PL 122, 955 D. 
Sólo puede castigar lo que no existe en lo que existe, es decir, a la perversa voluntad, que casi no es sustancial» ${ }^{185}$

Para el Eriúgena, como antes para San Agustín, el mal moral consiste y coincide en la deficiencia o en la ausencia de un bien necesario, o en el mal uso de la voluntad. Y si la cusa del pecado es la volubilidad-mutabilidad de la voluntad, que deja al hombre indeterminado para el bien o para el mal, esa voluntabilidad-mutabilidad es ya en sí un mal ${ }^{186}$, porque su causa es la ignorancia, aunque sin ella el hombre no sería verdaderamente libre, y la justicia divina no tendría sentido, ni la ley, ni los preceptos divinos. ¿Qué significado tendrían los mandamientos para un hombre que no pudiera obrar más que el bien? Solamente con el libre albedrío el hombre tiene la posibilidad de aceptar o rechazar la gracia; $y$, con ello, obtener mérito o culpa ${ }^{187}$, porque en Dios tampoco la pena y el pecado existen en él, en quien sólo se encuentra la presencia del ser y del bien ${ }^{188}$.

También, y como en San Agustín ${ }^{189}$, en Escoto Eriúgena el mal se reduce al pecado. Pero, mientras que en San Agustín la única causante es la mala voluntad, para el Eriúgena es la voluntad, es el libre albedrío, el que es capaz de decisión en libertad de aceptar o rechazar; por lo que se puede concluir que la causa del pecado es la versatilidad de la voluntad. Esta versatilidad es ya en sí un mal -como hemos dicho más arriba-. Pero tenemos que pensar que sin ella el hombre no sería enteramente libre. Porque si Dios le hubiera concedido al hombre la sola inclinación hacia el bien y vivir conforme a la justicia, éste no sería enteramente libre, porque se vería en la determinación fijada de escoger siempre el bien; y sería un poco libre y otro poco no-libre. Y esto para el Eriúgena es imposible: para él es completamente libre o no lo es, si no lo es, es que se destruiría la naturaleza humana. Un libre albedrío que se tambaleara, no puede mantenerse firme en pie ${ }^{190}$. Y se pregunta: ¿qué significa dar mandamientos al hombre para evitar el mal y obrar el bien, si el hombre no puede por menos que realizar el bien? Entonces se concluye que Dios tuvo que dar al hombre el completo albedrío con el cual puede pecar o mantenerse en fidelidad a Dios. Y así, con este libre albedrío pleno, el hombre se capacita para usufructuar la ayuda que se le viene con la gracia de Dios ${ }^{191}$.

185. Ibidem, V, 35; PL 122, 959 D.

186. Ibidem, IV, 14; PL 122, $808 \mathrm{C}$.

187. De praedestinatione, V, 9; PL 122, 379 A-D.

188. Ibidem, XV, 8; PL 122, 416 A-C.

189. San Agustin, De natura boni, 36; De libero arbitrio, I, 16, 35; Confessiones, VII, 3, 4.

190. De praedestinatione, V, 8; PL 122, 378 C.

191. Ibidem, V, 9; PL 122, 379 C-D. 


\section{X.- CONClusion: ¿PANTEISMo, NO PANTEISMO EN JUAN Escoto ERIUGENA?}

Este es un problema discutido y discutible por todos los que se han encarado con la doctrina de este oscurísimo y original teólogo-filósofo, que es Juan Escoto Eriúgena. Y en este apartado tenemos que tener en cuenta la influencia del neoplatonismo en su pensamiento, que es lo que queremos hacer nosotros, como presupuesto para saber si el Eriúgena es o no. es panteísta.

Todos admiten la dependencia suya del neoplatonismo, porque para él el ser está jerarquizado. Y como dice Hirschberge ${ }^{192}$, el punto de gradación de cada ser señala una altura de valor. En la cima de todo está Dios, como en la pirámide de Platón el Bien y el Uno, el sumo de todo, en Plotino, de donde todo fluye y emana. En el Eriúgena Dios es el Increado y el Creador de todo -natura creans increata-. En Dios existen y subsisten todas las ideas primordiales, y en ellas Dios se despliega a sí mismo desde toda la eternidad y, con ello, crea también el devenir. Estas causas primordiales -en San Agustín razones eternas - son la causa verdadera de todas las cosas mundanales existentes. En la creación del mundo estas mismas ideas son las que confieren el ser al cosmos y al hombre mismo. Porque ellas son toda la eficacia y virtualidad de los seres. Por consiguiente, Dios es todo en todas las cosas, y el mundo es una epifanía de Dios. Con todo, el mundo bajo-sensible no reproduce estas ideas en toda su pureza, pero hacia ello tiende. El mundo está como en suspiro constante hacia un regreso-retorno a su procedencia, especialmente el mundo humano, que siente ansias trágicas de volver a su inicio tras un proceso dinámico de purgación-mortificación. Con esto parece que se convierte el pensamiento del Eriúgena en algo parecido a una filosofía de la identidad al estilo de Proclo.

Se ha hablado mucho del panteísmo del Eriúgena. Y, de hecho, el papa Honorio III, con ocasión de que Amalrico de Béne quiso apoyar su panteísmo en el Eriúgena, condenó la obra del Eriúgena, La división de la naturale$z a$, en 1255.

No podemos identificar el panteísmo del Eriúgena con lo que hoy entendemos por panteísmo. Porque toda la obra de Escoto está encaminada a dirigir el conocimiento hacia la grandeza del Dios creador de todo. El no escribe de modo distinto al que lo hicieron Gregorio de Nisa, el Pseudo dionisio, Máximo el Confesor y San Agustín. Puede ser que en él quede menos acentuada la distinción entre Dios y el mundo. Pero, en el fondo, tenemos que

192. Hirschberger, J: Historia de la filosofía, tomo I, pág. 268. ED. Herder, Bardelona, 1963. 
confesar que se da, porque las ideas primordiales, existentes en la mente de Dios, no son de la misma calidad de eternidad que la eternidad de Dios, porque son creadas, si se quiere desde toda la eternidad, pero creadas. Tampoco el mundo sensible se identifica con la idea, como tampoco se identifica en el platonismo auténtico. Pensamos que sólo son semejantes; y la semejanza nunca equivale a identidad-igualdad. $\mathrm{Y}$ esto lo podemos ver en el neoplatonismo agustiniano medieval.

Siempre será muy arriesgado pensar en un panteísmo en Juan Escoto Eriúgna. Una cosa debemos dar como cierta: la identidad del mundo y de Dios es afirmada por él en la dirección que va del mundo a Dios y no en la que va de Dios al mundo. Con lo que podemos afirmar que hay siempre una distancia de Creador y criatura, porque las causas son distintas de sus efectos. Y así dice el Eriúgena:

«Dios está sobre todas las cosas, porque sólo él es. Y, aun siendo todo en todas, no cesa de ser todo él furea de todas. Él es todo en el mundo, todo alrededor del mundo, todo en la criatura sensible, todo en la criatura inteligible. Es todo en el crear del universo, es todo en las partes de él, porque él mismo es todo y parte y no ni todo ni parte» ${ }^{193}$.

Es decir, y a pesar de estas palabras que, a primera vista son una confirmación de su panteísmo, no creemos que él sea tan insensato que identifique la sustancia de las cosas, cradas por Dios, con su propia sustancia. Pensemos que él es un cristiano y no puede confundir a Dios consigo mismo o con las otras cosas. Por lo que podemos concluir -y estamos en nuestro derechoque Dios no se identifica nunca con la totalidad del universo, porque, aun adentrándose en sí, lo trasciende, porque es su criatura. Y con esto se salva del panteísmo. 